\title{
The International Engineering Service Program at the University of Iowa
}

\author{
Flora E. Duff \\ Junior Undergraduate Student \\ Civil \& Environmental Engineering \\ Lee W. Hauser \\ Graduate Student \\ Environmental Engineering \& Science \\ Timothy J. Houser
Shop Staff
IIHR - Hydroscience \& Engineering
}

\author{
Lindsay J. Marshall \\ M.A. Applied Anthropology \\ Iowa Center for Research by Undergraduates
}

\author{
Hayden W. Ausland \\ M.S. 2014 \\ Environmental Engineering \& Science
}

\author{
Benjamin Kusi \\ Country Director for Ghana \\ Self-Help International
}

\author{
Craig L. Just* \\ Assistant Professor, Civil \& Environmental Engineering \\ University of Iowa, Iowa City, Iowa USA \\ 4111 Seamans Center for the Engineering Arts and Sciences \\ craig-just@uiowa.edu \\ *corresponding author
}

Abstract - The International Engineering Service Program at the University of Iowa (UIIESP) has evolved immensely since 2003. The UI-IESP changed significantly in response to increases in financial resources from grants and gifts and through the creation of the Design With the Developing World (DWDW) service-learning course. Taught since 2006, the DWDW course has provided 185 students the opportunity to work in interdisciplinary teams to propose solutions to problems faced by people in the "developing world". Since 2013, improvements to the DWDW course include a change in instructional format, the utilization of the Field Guide to Environmental Engineering for Development Workers, the integration of experiential workshops, and the UI-IESP partnership with Kobriti, Ghana. The Kobriti Partnership recently culminated in the construction of a solar-powered groundwater pumping system by the people of Kobriti with the assistance of a UI-IESP team that included three former DWDW students, a university shop staff member and a university research staff member. Using reflections written by students, the research staff member and the corresponding author, the UI-IESP was determined to be effective overall. Critiques of the UI-IESP highlighted the lack of a national affiliation, the use of a single advisor, the small international scope, the perception that the DWDW course was unable to fully prepare students, and the need for redundancy in communication planning. Lessons learned include "knowing by going", being resilient, embracing unknowns, respecting indigenous knowledge, and always seeking partners. Best practices include diverse training for students, partnering for the long-term, identifying responsible parties, partnership reciprocity, and utilizing resources from the university, EWB-USA and/or ESW.

Index Terms - course design, interdisciplinary, international development, student reflections 


\section{INTRODUCTION, HISTORY AND FUNDING OF THE INTERNATIONAL ENGINEERING SERVICE Program AT THE UnIVERSITY OF IOWA}

The International Engineering Service Program at the University of Iowa (UI-IESP) was commissioned in 2003 by then engineering dean, Dr. Barry Butler. The UI-IESP was to focus on service-learning in international settings with engineering and non-engineering students engaged in interdisciplinary projects with communities seeking to develop sustainably. The UI-IESP framework was influenced by local, visionary Rotarians with strong ties to the university and to the college of engineering. Beginning in 2003, these Rotarians organized a series of spring break trips to Xicotepec, Mexico, that included corresponding author, university students, and local community members. For the annual trips between 2003 and 2006, preparations in the weeks leading up to spring break became increasingly hectic as the various water projects being implemented became more and more complex. Additionally, some students were ill-prepared for the cultural immersion experience and some minor, negative outcomes in partner-community relations resulted. To address these issues, a 3 credit-hour, service-learning course was conceptualized by the corresponding author in the spring of 2006 as a component of the broader UI-IESP.

Serendipitously, in the summer of 2006, the University of Iowa, Center for Teaching hired Dr. Ed Zlotkowski to deliver a week-long institute to train 16 faculty on the pedagogy of civic engagement and service-learning. ${ }^{1-5}$ The corresponding author was selected to participate in the institute with the condition that the corresponding author develop and offer a service-learning course. This experience led to the creation of the Design With the Developing World (DWDW) course that was launched in the fall of 2006. The intent was to offer the course each fall semester as a means to fully prepare myself and the students for the Xicotepec trip that would take place the following spring break. Design With the Developing World is a service-learning course that gives students the opportunity to work in interdisciplinary teams focused on issues (e.g. water \& sanitation, shelter, food security, education, energy and poverty) commonly faced by people living in the "developing world."6-17 Offered by the Department of Civil and Environmental Engineering, but open to all majors, the course enrollment is typically $65 \%$ future engineers and $35 \%$ non-engineers representing majors such as political science, anthropology, business, environmental science and global studies. Since its inception in 2006, the DWDW course has educated 185 students, undergraduate and graduate, and in 2009 was included as a 3 credit-hour project course option for the university-wide, undergraduate Certificate in Sustainability. ${ }^{18}$ During this same time period, the corresponding author also contributed to the design and implementation of an interdisciplinary, team-taught service-learning course, International Perspectives: Xicotepec ${ }^{19}$ that was first offered in the spring of 2007 and is still offered today as one component of the Xicotepec Project. ${ }^{20}$ The Xicotepec Project and the associated University of Iowa course is still considered a "sister program" to the UI-IESP despite the corresponding author's last direct involvement being in the spring of 2009.

The trajectory of UI-IESP was fundamentally changed when students from the fall 2006 DWDW course were awarded a \$10,000 Phase I project from the U. S. Environmental Protection Agency, National Student Design Competition for Sustainability Focusing on People, Prosperity and the Planet (USEPA P3). ${ }^{21}$ Prior to this award, the UI-IESP was funded annually at $\$ 3,000$ by the engineering dean with travel to Xicotepec funded by Rotary scholarships and personal fundraising efforts by students. The \$10,000 USEPA P3 award was used for travel to Xicotepec and for prototyping a handheld bleach generation device during the fall 2007 DWDW course. 
Amazingly, students from the 2007 DWDW course were subsequently awarded $\$ 75,000$ in 2008 for a Phase II EPA P3 project. This funding allowed approximately one dozen students and the corresponding author to travel to Xicotepec, and eventually Ghana, for product redesign efforts involving our international colleagues.

The geographic focus of the UI-IESP shifted away from the community of Xicotepec, Mexico, in the spring of 2009 when the corresponding author was invited by Self-Help International (SHI $)^{22}$ to partner on water projects in Kobriti, Ghana. This shift in community focus also led to a substantial change in the service-learning focus and pedagogy of the DWDW course. The eventual success of the "Kobriti partnership", the success of the USEPA P3 project and the continued success of the DWDW course were reasons cited for a lump sum $\$ 50,000$ gift to the University of Iowa Foundation in 2010 to support the UI-IESP. This gift was immediately followed by a $\$ 5,000$ per year, 10 year commitment from an additional benefactor - an alumnus of the University of Iowa. In the absence of these financial resources, the UI-IESP would not exist in its current form.

It is also important to note that the UI-IESP has been heavily influenced by Engineers for a Sustainable World (ESW) and Engineers Without Borders USA (EWB-USA). The corresponding author was involved with a group of University of Iowa students who were early participants in the ESW organization. The University of Iowa hosted the ESW national conference in the fall of 2006 and the corresponding author served in various ESW advisory board positions. The University of Iowa ended its ESW student chapter affiliation in 2011. The University of Iowa started a EWB-USA student chapter in 2007 and the corresponding author served on the EWB-USA Faculty Leadership Council. A EWB-USA program was established for Kobriti, Ghana, but no projects were implemented under the EWB-USA banner (projects were implement under the UI-IESP banner though). The University of Iowa ended its affiliation with EWB-USA in the fall of 2013. ESW and EWB-USA are great organizations and each offers a unique means of supporting university engineering programs that impact communities. But, the University of Iowa also has a unique ability to support the UI-IESP in its endeavors to impact communities which eventually made ESW and EWB-USA less attractive, mostly for financial and administrative reasons.

To assist those who may wish to start a new, or revise an existing, university engineering program that impacts students and international communities we share:

- the history of and funding sources for the UI-IESP;

- a snapshot of the design and evolution of the DWDW course (with accompanying syllabi) that is a component of the UI-IESP;

- the history and impact of the "Kobriti Partnership" on Kobriti and University of Iowa students;

- research staff member and student reflections on the Kobriti Partnership and the DWDW course;

- a UI-IESP critique, lessons learned, and best practices drawn from DWDW course experiences, from the Kobriti Partnership, from the UI-IESP member reflections, and from the corresponding author.

To describe the impact the UI-IESP has had on Kobriti we utilized insight from SHI, Ghana Country Director, Benjamin Kusi, and critical reflections from the corresponding author. To 
discern the UI-IESP impact on university students, we utilized written reflections prepared by members of a team of three students, a university research staff member, and a university engineering shop staff member who completed a water project in Kobriti in the summer of 2014. The full reflection from "Student 1" alone is shared for brevity, but the reflections of all three students helped shape the overall program critique. The research staff member provided a personal reflection, an individual assessment of "Student 1" and a combined assessment of "Students $2 \& 3$ ". A University of Iowa staff member on the trip was not assessed and did not provide a reflection. The corresponding author was in Kobriti immediately prior to, but not during, the implementation team's efforts and was not assessed by the research staff member.

\section{Design ANd Evolution of THE Design With the Developing World Course}

\section{Course Design Snapshot:}

The DWDW course provides students the opportunity to work in interdisciplinary teams to propose solutions to problems people face in the "developing world". Appropriate technologies to improve water and sanitation, energy, housing, and health are studied and developed. Community building strategies, participatory methods and other techniques essential to a good design are explored. Much of the learning in the course is facilitated through teamwork and peerto-peer dialogue and activities as guided by the course facilitator. The DWDW course initially met twice per week from 4:30-5:45 p.m. with the late meeting time selected to enable students of various majors to enroll (see the 2007 course syllabus in Appendix A). A desirable course textbook could not be found, so a variety of resources including:

- the UNESCO Small is Working ${ }^{23}$ video and booklet;

- the Introductory Engineering Design: A Projects-Based Approach ${ }^{24}$ resource from the University of Colorado at Boulder;

- $\quad$ the Millennium Development Goals Report ${ }^{25}$;

- and a variety of 2-4 page, online "appropriate technologies" guides from what was then the Intermediate Technology Development Group and which is now Practical Action. ${ }^{26}$

Points were earned for quizzes, individual, team-based and service-learning assignments and for a series of short team design-and-build challenges and a semester-long, team-design challenge. The semester-long design challenge from the fall of 2007 went on to win the $2008 \mathrm{U}$. S. Environmental Protection Agency, National Student Design Competition for Sustainability Focusing on People, Prosperity and the Planet (USEPA P3). ${ }^{21}$

Aside from this success, a major course design challenge has been to identify representative service-learning opportunities in a resource rich community such as Iowa City. In course offerings in 2006, 2007 and 2008, this challenge was addressed by focusing on service-learning in a more local context, for example:

- feeding the hungry via the Wesley Center, a campus ministry group;

- water purification education at Coralville Central Elementary School;

- creating permanent shelter with Habitat for Humanity;

- and building emergency shelter in partnership with Shelter House, the local general use homeless shelter. 
But, in the fall of 2010, an influx of students pursuing the Certificate in Sustainability caused course enrollment to increase from 23 to 47 and the ability of the local community partners to accommodate service-learning was greatly diminished. Additionally, from the corresponding author/course instructor's perspective, the administration of these intimate service-learning relationships became far too burdensome. The successful course design of the past did not scale to the larger student enrollment, so the service-learning component was mostly abandoned for the fall 2010 DWDW course offering. The course was not taught again until the spring of 2013.

\section{Course Redesign Snapshot:}

The DWDW course was redesigned prior to the spring 2013 offering to address the increased enrollment issue and to see if successful UI-IESP engagements in Ghana that took place between 2009 and 2012 could provide an adequate service-learning context (see the 2013 course syllabus in Appendix B). Another important element of the redesign was the full integration of the electronic computing and team-oriented workspace afforded by a "TILE" (Transform, Interact, Learn, Engage) classroom. ${ }^{27}$ The TILE classrooms combine active-learning pedagogy, enabled by technology and class equipment configuration (Figure 1).

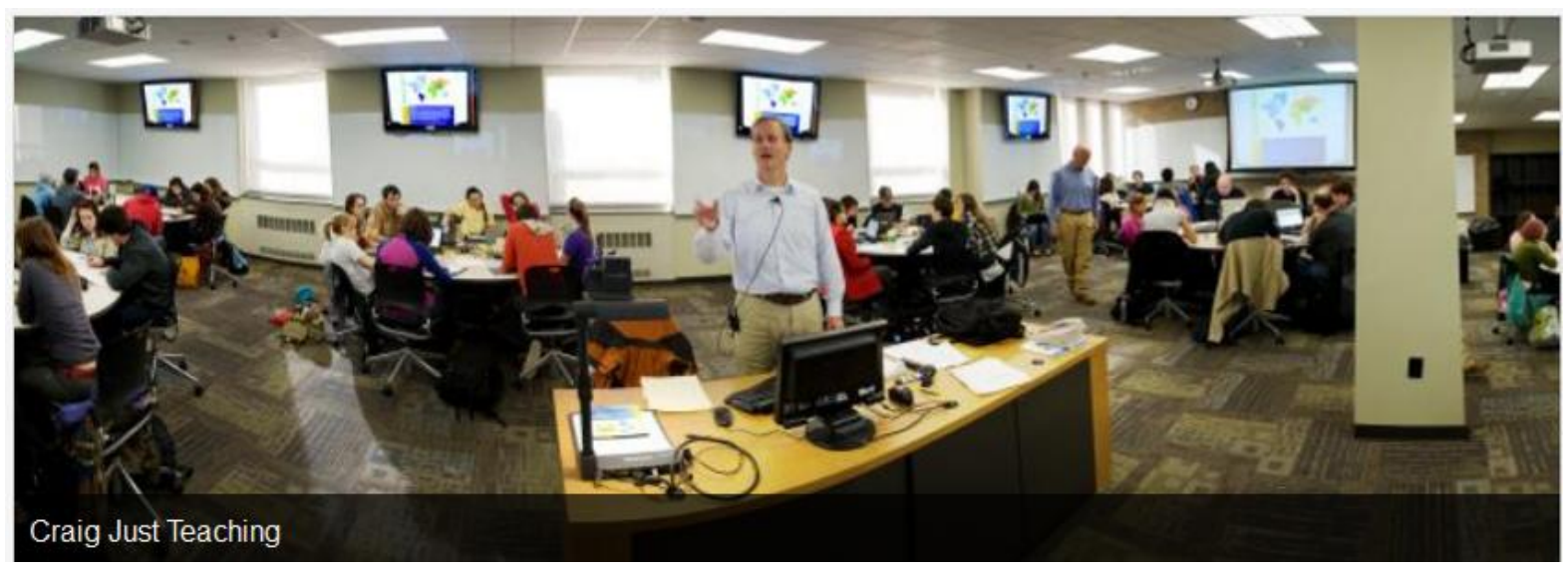

FIGURE 1

THE CORRESPONDING AUTHOR TEACHING IN A UNIVERSITY OF IOWA TILE CLASSROOM. PHOTO TAKEN FROM HTTP://TILE.UIOWA.EDU

The TILE classroom allows student teams to be situated at round tables with dedicated laptops, a flat-screen television and a white board. The instructor console is located in the center of the room which tends to minimize "sage on the stage" style instruction in favor of a "guide on the side" approach. Students can quickly research topics of interest on the internet and share reports and video links with team members or the entire class.

Another component of the DWDW course redesign was the full incorporation of the course "textbook", the Field Guide to Environmental Engineering for Development Workers. ${ }^{28}$ The Field Guide was used in the 2010 course offering mostly as a design guide for various projects and for open book exams and quizzes. In 2013, a series of online questions and short problems were developed to assess student awareness of content and concepts contained within the Field Guide. Consistent with a "flipped" course design ${ }^{29-31}$, the content from the Field Guide is 
explored by students mostly outside of class time via a course management system. ${ }^{32}$ These online assessments were designed to ensure that students display a breadth of exposure to course content prior to classroom instruction. Learning at depth is facilitated through in-class activities and through team designs where course content is applied towards working through specific challenges, such as "reinventing the toilet". 33

Learning is also displayed through a series of workstations housed in a campus warehousestyle shop facility where students use Abney levels, pour concrete latrine floors, construct a solar-powered water pumping system, chlorinate a water tower, and lay foundation block in team settings (Figure 2). The course meeting time was changed from twice weekly to once per week from 6-9 p.m. to accommodate these workshops. This change improved the classroom experience as well since interactive research and design in team settings often requires longer time blocks for success. It was also anticipated that students would bring their Field Guide to the workshops as a reference, but many students were using an electronic version available through the engineering library. Some students accessed the Field Guide via personal smart phones or tablets while participating in the workshops.

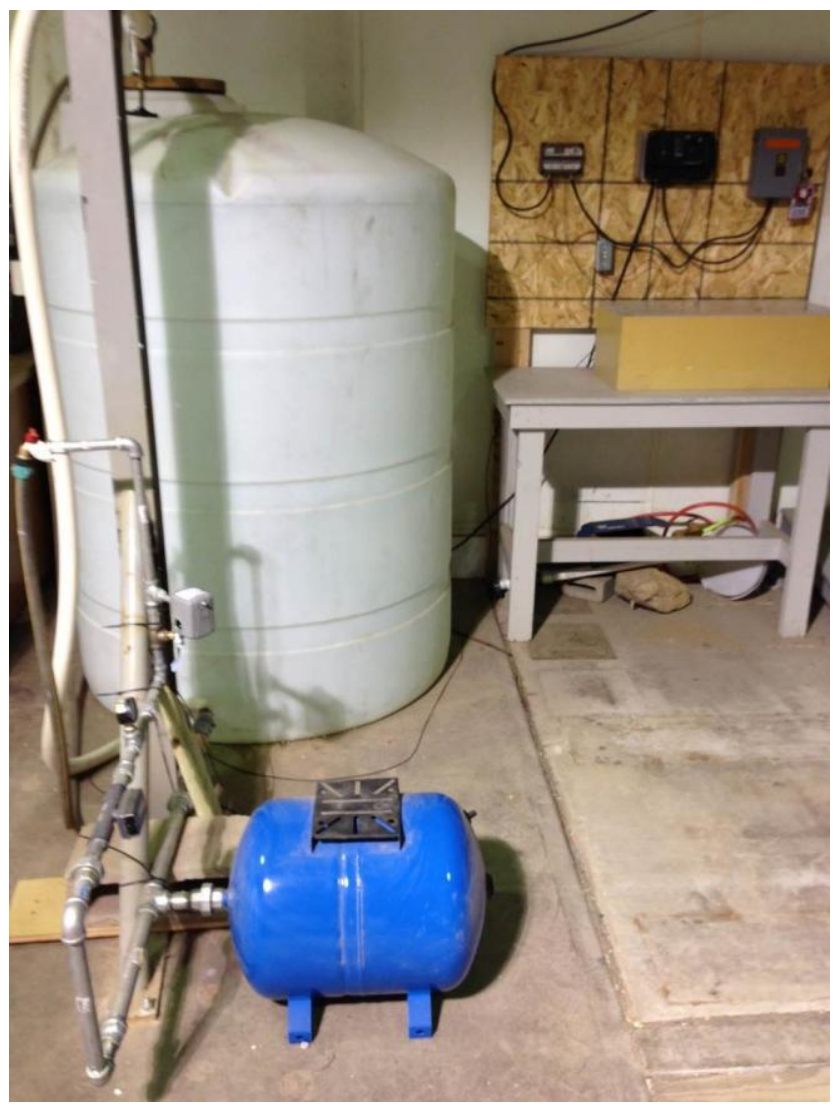

FIGURE 2

SOLAR-POWERED BOREHOLE WATER PUMPING WORKSTATION USED IN THE DESIGN WITH THE DEVELOPING WORLD COURSE

The most important element of the redesign is that all learning is pursued in the context of the needs of our service-learning partner - the people of Kobriti, Ghana. As a product of the USEPA P3 project mentioned earlier, the corresponding author gave a presentation titled "More 
Affordable Handheld Water Sanitizers" at the 2009 Annual Meeting of the American Association for the Advancement of Science in Chicago. A subsequent story by the University of Iowa News Services ${ }^{34}$ was read by the executive director of SHI based in Waverly, Iowa, who then invited the corresponding author to join them in their work in Ghana. Despite the separation of thousands of miles, the Kobriti Program (detailed below), has brought a new richness to the DWDW course. The small community of Kobriti is "brought to life" for the students through the sharing of stories, pictures and video ${ }^{35}$ of past engagement trips. Via the course, students have advocated for solutions to water issues in and around Iowa City and for Kobriti, Ghana, with hopes that the ensuing dialogue will lead to better designs for current and future projects that will ultimately benefit people in need. But, despite efforts to provide a learning environment that is contextualized by others' previous experiences in Kobriti, the students are always told "if you don't go, you don't know". This is a long-time tenet of the D80 program at Michigan Tech University $^{36}$ as quoted from New York Times columnist, Thomas Friedman. Through a series of interviews and reflections on course performance, three former DWDW students were selected to travel as part of a team to Kobriti, Ghana, in the summer of 2014. These students joined a cohort of nearly a dozen other former students since 2009 that now "know" because they got "to go".

\section{THE History AND IMPaCt OF THE "KobRITI PARTNERSHIP” ON KOBRITI AND ON UNIVERSITY OF IOWA STUDENTS}

The mission of the Kobriti Partnership is to partner with Kobriti and other villages in the Ejura Sekyedumase District in Ghana, West Africa, (Figure 3) on "global health engineering,"37, 38 projects focused mainly on community drinking water and sanitation. Staff from the SHI division based in Kumasi, Ghana, hosted the first of several UI-IESP meetings in Kobriti in January of 2009. At these meetings, District officials from the Community Water and Sanitation Agency (CWSA) reported that many communities lacked access to safe drinking water and were without proper resources for disposing of human excrement.

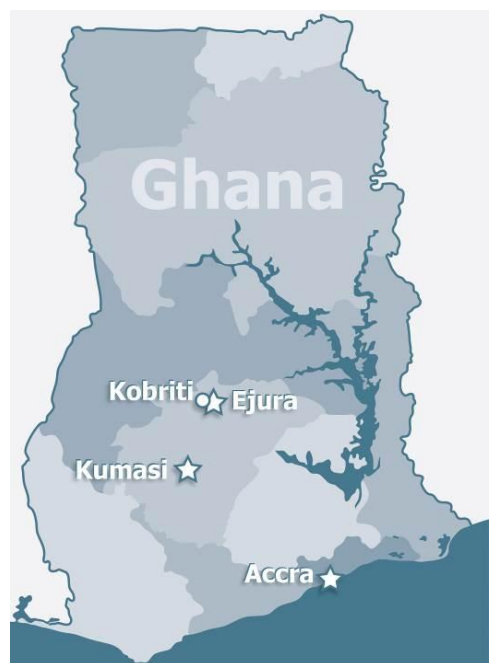

FIGURE 3

A MAP OF GHANA, WEST AFRICA, WHICH HIGHLIGHTS THE CITIES OF ACCRA, KUMASI, EJURA AND OUR PARTNER COMMUNITY, KOBRITI. 


\section{Community Background and Assessment:}

Kobriti is located about 20 minutes from the city of Ejura (Figure 3). The population of approximately 600 represents about 70 individual households with many people being farmers. The residential shelters are made mostly of mud and some have structural frames made from tree branches (Figure 4). Kobriti does not have electricity, but the arrival of this resource has been promised by District authorities for many years. While some of the people maintain their northern dialects, the vast majority are proficient in Twi, the language of the Ashanti region. Only a few residents are proficient in English, a majority of whom are teachers at the local school.

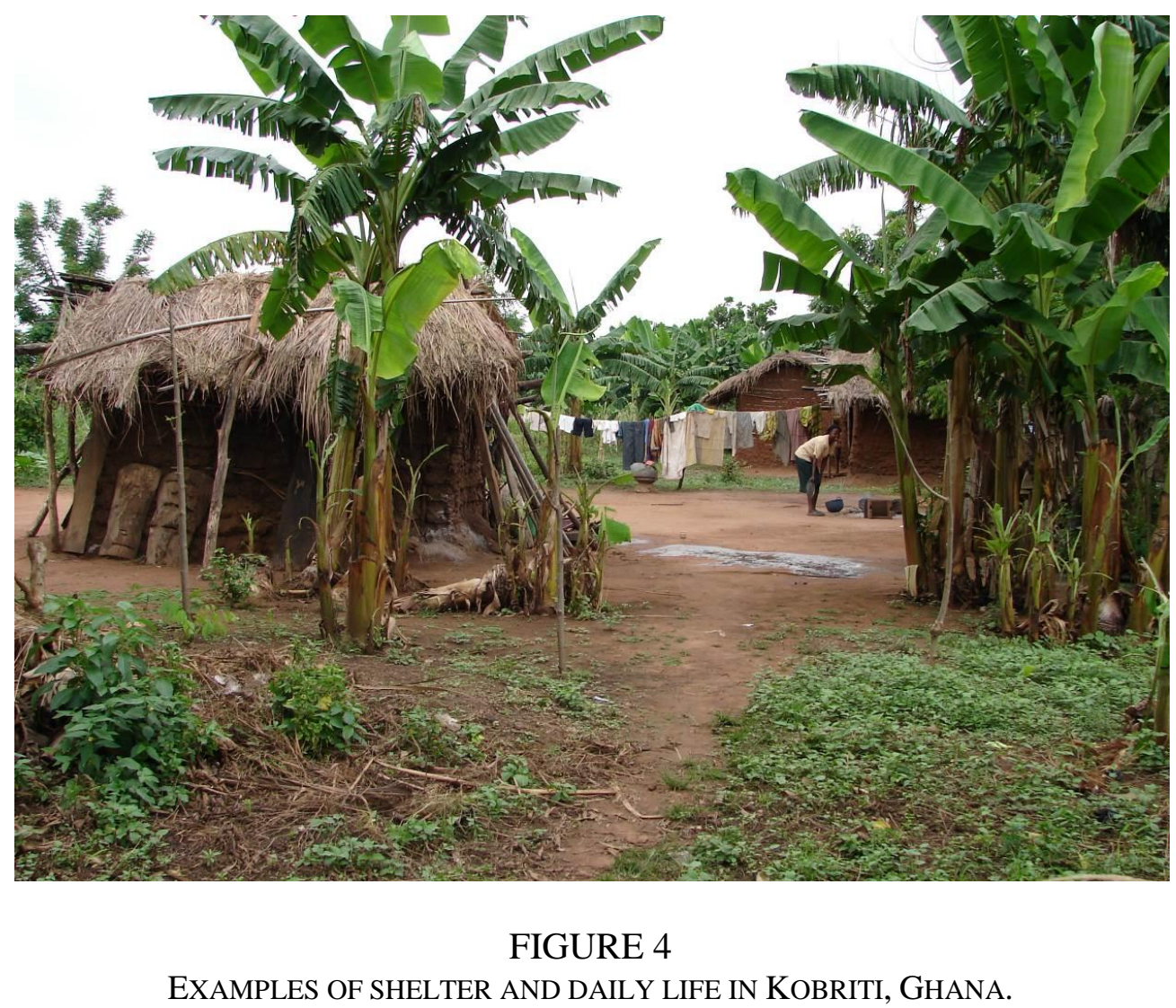

Kobriti's drinking water comes from two centrally located boreholes (Figure 5) with handoperated well pumps manufactured in India. Community leaders expressed concern over seasonal variations in water quality that reportedly resulted in the growth of visible organisms in water storage vessels. The CWSA staff person warned the community not to allow children to stuff food waste into the well pump orifice with the assumption that this might be causing the reported water contamination. 


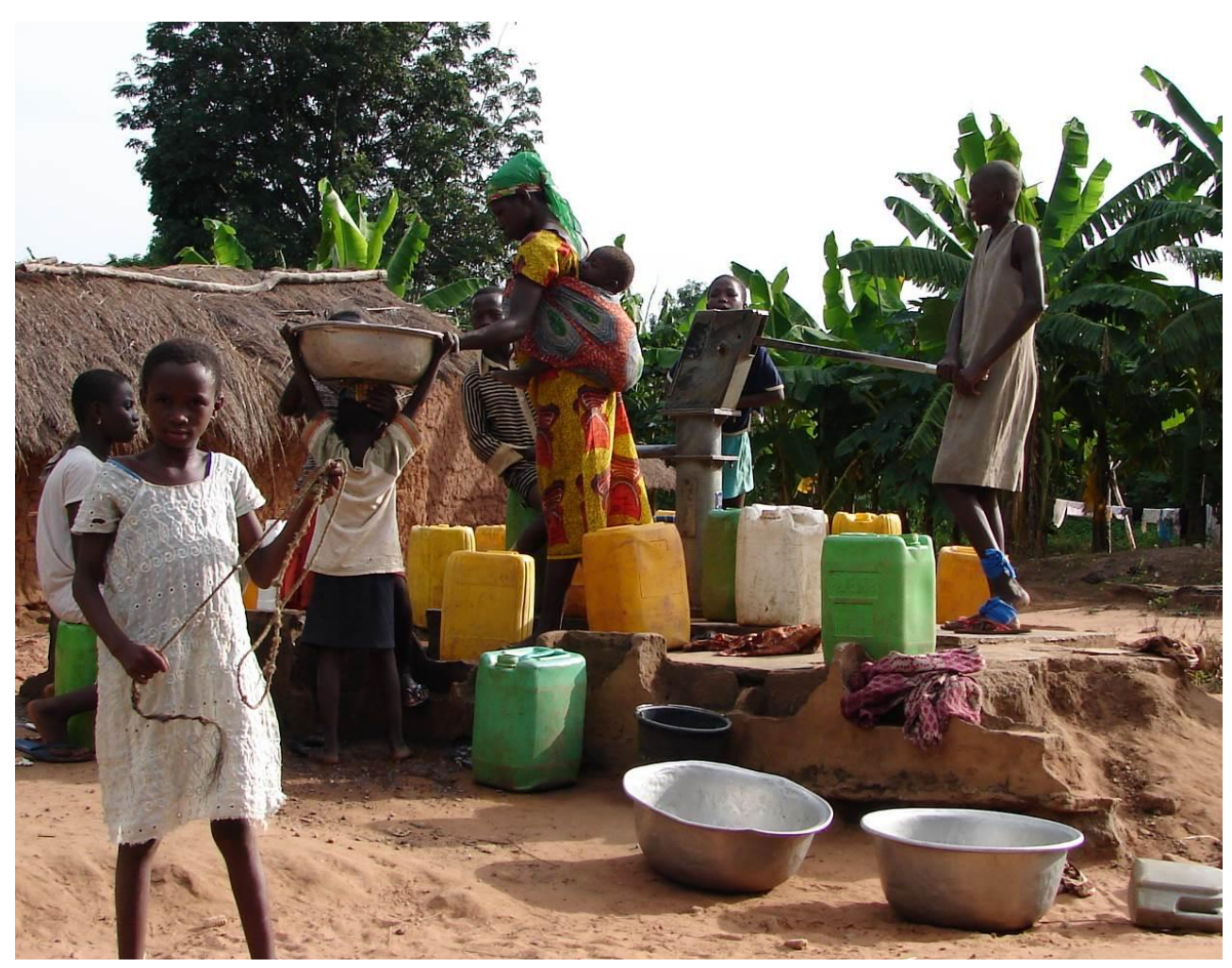

FIGURE 5

BOREHOLES WITH HAND PUMPS PROVIDE DRINKING WATER FOR KOBRITI.

Recognizing the complexity of the community's relationships with water and sanitation, an additional project scoping trip took place in January of 2010 that involved three UI-IESP students and the corresponding author. This trip was followed by a five week community assessment in June and July of 2010 involving four UI-IESP students and the corresponding author (in Ghana for 10 days only). During the five week assessment, time was spent in Kobriti observing how people interacted with each other and with their water resources at different communal areas. Time was also spent learning some of the local games, mostly played by the children, as well as learning some common phrases of the Twi language. A household-byhousehold community health survey was undertaken with a SHI staff member and a local teacher serving as translators. Additionally, the UI-IESP team met with the Ejura Sekyedumase District assembly that is responsible for the allocation of funds and that prioritizes District programs and projects and a formal partnership agreement was prepared and jointly signed. 
Impact: The people of Kobriti received the full attention of the District CWSA staff while UI-IESP members were present and the need for further education regarding water handling and safe storage practices was made apparent. The five week assessment trip made it clear to the people of Kobriti that the UI-IESP was serious about the partnership and that community voices were important. It was clear that the UI-IESP wanted to know as much about the community as possible before proposing any engineering projects. A team member on the five week assessment trip was a third-year medical student who was able to provide simple wound care and recommend if people should seek treatment by a doctor. This immediate ability to contribute to the wellbeing of the community paid long-term dividends for partner relations. The students on the five week assessment trip took pictures of every family and had them printed as gifts that were given at the end of the trip. This truly warmed the hearts of the people of Kobriti (as expressed by SHI Ghana Country Director, Benjamin Kusi). The students reported that their lives were forever changed and that the people of Kobriti were like "family".

\section{Kobriti Prioritizes a New Borehole:}

Community priorities were established through the triangulation of the community health survey responses, along with information gathered from all-community town hall meetings and discussions with community elders that were facilitated by students. Triangulation is a methodical approach that works to establish the validity of the research when multiple sources are involved, to explore ideas of convergence, complementarity, and dissonance. ${ }^{39-41}$ The overall goal here was to create a multidimensional understanding of Kobriti's relationship with, and needs regarding, water and sanitation. The community health survey data included 459 individual responses from 69 unique households that provided informed consent according to an approved internal review board protocol. Response analysis revealed that $84 \%$ of the families expressed water quantity as their greatest water concern despite individuals reporting that $68 \%$ defecate in nearby fields with only $23 \%$ using a dug hole. More water was often associated with drilling another borehole. When asked directly whether sanitation in the form of latrines or greater quantity of water was more important, the responses were split nearly evenly. One ventilated improved pit (VIP) latrine was built near the school in Kobriti with non-governmental organization help, but direct observation revealed the facility was not well kept and lacked resources for wiping and for hand washing. Perhaps this lack of cleanliness and the associated smell explains why many people specifically requested household latrines instead of the VIP design.

Additional town hall styled meetings were held in Kobriti in January of 2011 and January of 2012 that included dozens of community members, District CWSA staff, SHI staff and UI-IESP students and the corresponding author. At both of these gatherings, a new community borehole to supply drinking water was presented as the potential project of highest community priority. The community elder, Naba, was also consulted in private where he gave his blessings toward the construction of a new borehole. The UI-IESP team then began discussions with a private well company based in Accra, Ghana, which culminated in the drilling of a new borehole approximately 8 months later, in the summer of 2012. 
Impact: Triangulation toward a true community solution led to the best project for the Kobriti Partnership. The community health surveys revealed that Kobriti had an elevated, but manageable, diarrheal rate that could perhaps be reduced with improved water access for sanitation. The special attention given to Naba by the team affirmed his status as the community elder and elevated the reputation of the UI-IESP in the community. The students were able to facilitate a successful community consensus building effort that serves as a model for similar work they will face in their professional careers.

\section{Kobriti and the UI-IESP Partner to Design and Build a Borehole Pumping System:}

Prior to the completion of the borehole, a geophysical survey, at a cost of approximately $\$ 1500$ USD was undertaken. In January 2012, a few days after the surveying crew had left Kobriti, a community meeting was facilitated by District CWSA staff and SHI to announce the location of the new well. Two UI-IESP students were present to observe and document the community response. Immediately after the announcement, a few community members began to exchange words in Twi using loud voices accompanied by finger pointing. After emotions settled, it was shared that the proposed well location, near the school, was within an unmarked burial site known to only a few elders. As a result, this first proposed location for the new well was not feasible. In consultation with SHI staff, a new geophysical survey was commissioned at additional expense. The SHI staff served a critical role in seeing that the selected well drilling company completed all contracted work, as the UI-IESP team was no longer in country, which highlights the importance of maintaining excellent partnerships. The borehole was pump tested in the fall of 2012 and then capped to protect the source water until a pumping system would be installed.

In May and June of 2014, after months of planning and supply staging, a UI-IESP team of three former DWDW students (one female, two males), two staff members (one male, one female), and the corresponding author (male) partnered with the people of Kobriti to install a solar-powered well pump with enclosure. The system has a Grundfos submersible pump (11SQF-2) installed approximately 125 feet below surface, a 2.5 gallon pressure tank, a Grundfos pump control unit (CU-200), a 48 volt charge controller (ProStar-30), four 12 volt truck batteries, and two 90 watt, mono-crystalline solar panels. These components and others are the same, or similar, to those shown in the DWDW workstation photograph (Figure 2). The local tradesmen designed the concrete foundation for the pump house and implemented a splash pad design. The pump house, designed and built by Ghanaian tradesmen, is of metal construction with a lockable entrance, tin roof and barbed wire, which was installed to deter would be solar panel thieves. The water tested free of bacteria after shock chlorination and the arsenic concentration was below 1 part per billion. The people of Kobriti were excited to see this new community resource come to life after many years of planning and preparation. 
Impact: The partnership between SHI and the UI-IESP was strengthened through adversity. Benjamin Kusi (from SHI) described the fallout from the surveying mishap via email following the return of the UI-IESP team who witnessed the event. Mr. Kusi also provided advice that led to a determination that it was fair for the surveying company to return to Kobriti at additional cost. The students involved with the installation of the pumping system in the summer of 2014 expressed how the experience was extremely challenging, but life changing.

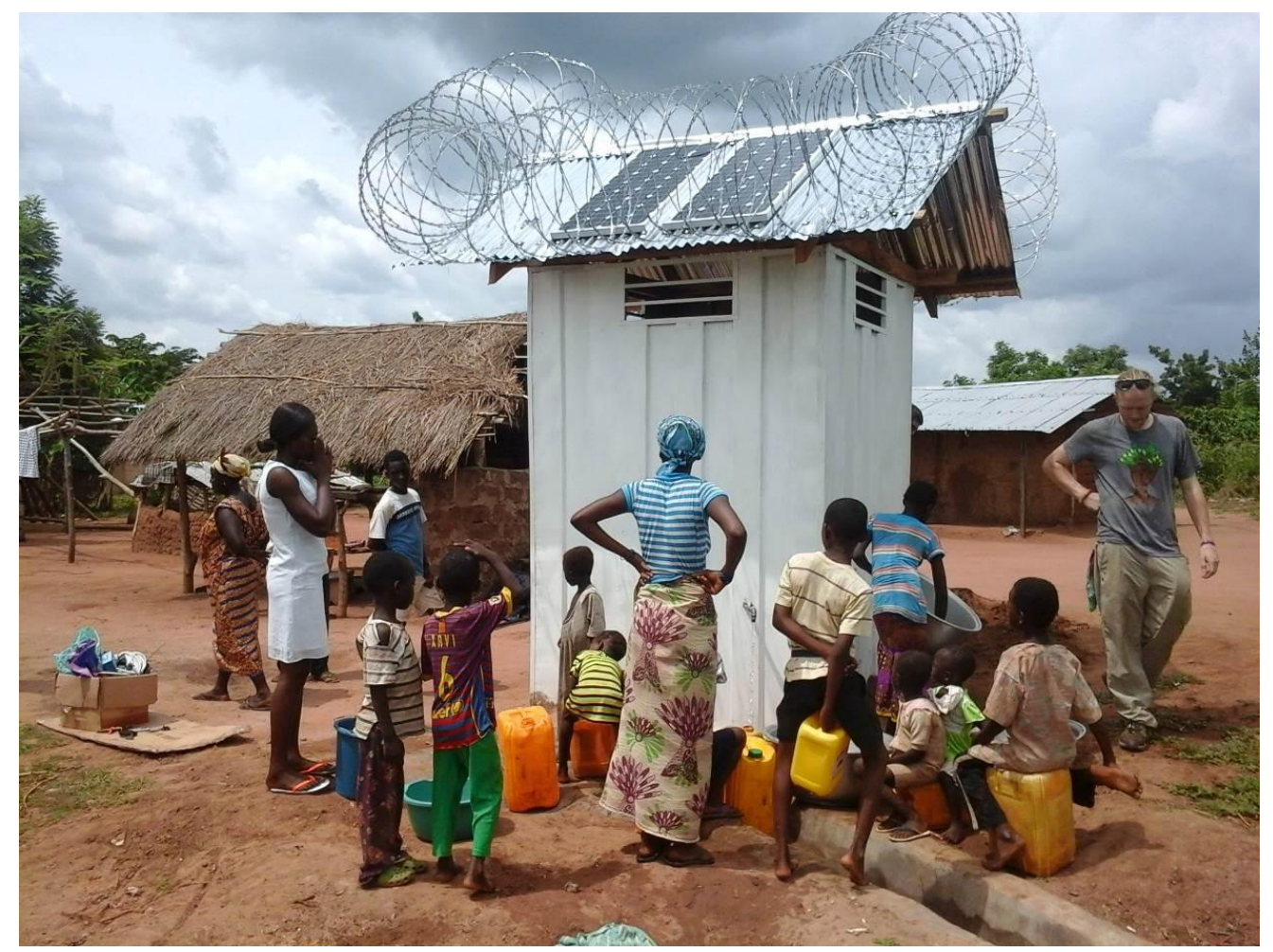

FIGURE 6

SOLAR-POWERED WELL PUMP WITH ENCLOSURE, SPIGOT AND SPLASH PAD. THE UI-IESP STUDENTS WERE TRAINED ON HOW TO INSTALL THE PUMPING SYSTEM COMPONENTS DURING THE DWDW COURSE. LOCAL

GHANAIANS DESIGNED THE SPLASH PAD AND ENCLOSURE TO THEIR OWN SPECIFICATIONS AS THE PROJECT PROGRESSED. 


\section{Student ANd ReSEarch Staff Reflections on the Kobriti PARTNERSHIP ANd THE DWDW COURSE}

Upon returning from Kobriti, the students were asked to reflect on their Kobriti Project diaries and prepare more formal written reflections regarding the extent to which the DWDW course prepared them for the experience. The students were asked to write specifically about course activities and philosophies that had an impact and they were asked to describe anything they felt was "missing" from the course in light of their Kobriti experience. Additionally, the research staff member provided observations and assessment of the student's experiences. The research staff member assessed the student's experiences in relation to the DWDW course. She went to team meetings prior to leaving the country, but did not attended the DWDW class. The research staff member became familiar with the course structure and content through reviewing the syllabus, materials, and talking with the students while traveling.

Two main methodological approaches - participatory rapid assessment and participant observation - were utilized in order to accurately situate the team member's perspectives and experiences. $^{42,43}$ Participatory rapid assessment requires the researcher to go into the field with clear, prepared questions and objectives. ${ }^{42}$ In this case, the primary question was "did the DWDW course prepare students to travel to Ghana?" Participant-observation, a strategic method employed to collect a wide array of data, from narratives, to numbers, to behaviors, was utilized with the purpose of building an ethnographic foundation for the project. It facilitates rapport building and the cultivation of relationships with those making up the research sample and allows the researcher to see how communities and groups function within their own environment. ${ }^{42-44}$ In this case, the research staff member was situated as a "participant observer" in so far as she was an insider who both observed and recorded aspects of the trip and person-toperson interaction. The research staff member also engaged in extensive memo-writing, a process of informal, analytical note-taking that allows the researcher to constantly compare and analyze data. ${ }^{45}$

However, before discussing the team's experiences, it is important to briefly contextualize each of them in regards to age, race, gender, training, and personality, all of which were important factors in their experiences. Student 1 is a female undergraduate student going into her senior year, majoring in Civil and Environmental Engineering. She is white, in her early twenties, and has traveled extensively throughout northern Europe, but never to a developing nation. Student 1 has an outgoing and friendly personality, with a very positive or optimistic demeanor. Student 2 is a male graduate student in Environmental Engineering who is white and in his mid-twenties. He has also traveled to Europe, but this was his first trip to a developing nation. However, Student 2 had the most experience with the Kobriti Partnership, as he had been engaged with the partnership for several years through UI-IESP and built the model pumping system on campus. Student 3, also a white male in his mid-twenties, had just completed graduate school in environmental engineering prior to leaving for Kobriti. He has traveled extensively both to developed and undeveloped nations. Student 3 had spent time in South America working on a different water project as an undergraduate engineering student and spent a significant amount of time studying the pumping system design for Kobriti. Student 2 and Student 3 are very similar in terms of personality, as they are both very level-headed, rarely becoming flustered and upset. The shop staff member is a white male in his mid-thirties who has extensive training in constructing engineered systems and had traveled to Kobriti once before. The research staff member is a white female in her late twenties who has traveled and worked in developing 
countries, and whose primary role at the University is to support students in research and handson learning experiences.

\section{First-person Student Reflection (Student 1):}

Together with other students enrolled in DWDW, I worked in interdisciplinary groups to propose new solutions to the various problems currently facing developing countries. Coursework included studying technologies to improve energy, housing, health, with a strong emphasis in water and sanitation. I would not have been even half as prepared as I was for our work in Ghana had I not taken the course. DWDW prepared me for living and working in Ghana's Ashanti Region more so than I could have imagined. While it is impossible to convey all of the many cultural differences within a 16-week course, Dr. Just's previous work in the region allowed us to better understand the issues we would face during our time there. The group who had worked with Kobriti before us prepared a slideshow and a video that allowed us to become more familiar with the community and their customs. Unfortunately, we did not have access to a translator familiar with these types of developments and the various problems and cultural customs associated with this type of work. Experienced advice might have increased the efficacy of our impact on the region. Through DWDW we learned, in detail, about issues facing developing countries. These include inadequate sanitation, malnutrition, and contaminated water. Awareness of these issues allowed us to avoid any detrimental impact on the community.

We focused on sustainability as the most important aspect of the project. We therefore found it even more important to receive the community's input, maximize the design life of our system, and determine with absolute certainty that no harm would come from the project. Another important branch of sustainability that Dr. Just emphasized in practice was remaining in touch with the community by completing follow-up site visits, ensuring continual development in the community. Rather than traveling to a country to complete a project and leaving without any follow up, Dr. Just constantly reminded the class that you may actually being doing more harm than good if you do not remain in contact with the people of the village.

My specific task on this trip was to perform water quality testing on AfriClay filters ${ }^{46}$, ceramic filters used to filter drinking water, that were distributed to the village a few years ago by our organization. Without a translator, it became difficult to complete surveys regarding the satisfaction or dissatisfaction of the filters with a community that, for the most part, only speaks Twi. The situation was one that we were unable to anticipate, and we quickly came to learn that nothing can prepare you for the unknown. Unexpected challenges quickly became apparent - the lack of a translator, the difficulty in acquiring materials, and other situations such as building our solar-powered water pump. We were, fortunately, armed with the knowledge that 'the unknown' would occur and had learned of various measures that can be taken to solve those issues. To communicate with those who owned filters, we recruited the assistance of the few people of Kobriti who spoke English, learned as many Twi phrases as possible, and expanded our water quality testing to sources other than the AfriClay filters. Although we faced challenges in completing the surveys with as much depth as we had hoped, we had more time to test other sources of water that we found the community using for drinking and bathing. We tested both of the two hand-pumps already in use within the community, the solar powered water pump our group had installed, and a large, lid-less, communal water storage container for the presence and concentration of fecal coliform bacteria. We were not surprised to find that the large lid-less 
container that the community dipped a common cup in was teeming with bacteria, and happy to see that the pumps had virtually no bacteria present.

In the first half of DWDW, we studied James Mihelcic's book, Field Guide to Environmental Engineering for Development Workers. This book is a how-to guide for applying engineering to clean-water access and sanitation standardization in developing countries. We were assigned relevant portions of the book to study on which we were quizzed weekly. Familiarity with the book and its contents turned out to be very important on our trip. I brought the book with me and found it very easy to quickly find the pertinent information. It ended up being our greatest tool as it was used to teach us how to test the arsenic content of our well's water and the range of acceptable levels, the proper way to build a well and a splash pad, and an in-depth background of developing countries.

The quote from the course that stuck with me the most is the saying that "you don't know until you go." I can't think of a better way to describe the effect that this trip had as it became an absolutely integral part of my college education. A complete change in perspective occurred as I grew to appreciate the many, many benefits that we experience as Americans. Dr. Just's course properly prepared me for this change in perspective. It is, however, impossible to be completely prepared to face all obstacles and challenges of a project of this magnitude.

\section{Research Staff Member's Reflection on Student 1:}

Student 1 was the most prepared in regards to her knowledge about Ghana, Ghanaian culture, and the Twi language. She spent a significant amount of time prior to the trip reading about Ghana and making notes of common phrases and pronunciations of Twi words. She brought that notebook with her - which proved to be an excellent resource for every member of the team adding words and phrases throughout the trip. This served her well, as she was able to easily build friendly relationships with nearly everyone the team encountered, simply by greeting others or answering questions using the Twi she had learned. She was also able to pick out key phrases when Ghanaians tried to speak with us in Twi and community members quickly learned and remembered her name. Much of the success in rapport building with the community can be contributed to Student 1's efforts. That said, her knowledge of the Twi language was still minimal and did not alleviate the need for a translator, especially in regard to building the system, acquiring materials, and locating and testing the AfriClay filters.

As an undergraduate engineering student, Student 1 was the least prepared in terms of technical ability, which is expected given that she had not yet had various design or coursework experiences. While she was familiar with how the solar-powered pumping system was supposed to function overall as a result of workshops she participated in during DWDW course workshops, she did not feel that she was able to contribute very much to the actual construction or troubleshooting of the system, which proved to be frustrating for her. However, since this was not her primary role on the team, it did not prove to be a hindrance to the execution of the project. In regards to her specific task on the trip, testing the AfriClay filters, Student 1 felt comfortable with the testing procedure and efficiently tested all of the water sources available (which turned out to be improvised). Locating the filters proved to be difficult, as she had to locate the few members of the community who spoke English (most of whom were teachers and had to work during the day while the team was on site) and try to ask them which community members had the filters. One teacher said she knew of people who had filters, but that Student 1 was not allowed to go into their homes to "see" the filters and did not actually tell her who had 
them, just that they were in fact in scattered around the community. It can be assumed that the short duration of this trip contributed to the difficulty in locating the filters, as a longer community rapport building period may have allowed Student 1 to more fully track and test the filters once the people of Kobriti were comfortable enough with her to let her in to their homes.

\section{Research Staff Member's Reflection on Student 2 and Student 3:}

Student 2 was the most prepared technically as he had been engaged with the project for several years and worked to build the model system on campus. Student 3 spent time outside of the class learning about how the solar panels worked and was familiar with the system and the principles behind it. However, it seemed that the biggest contributing factor to their success in the field is that Student 2 and Student 3 both have a solid engineering background and are skilled and comfortable constructing projects from start to finish (meaning that they aren't just classroom trained, but have actually built engineering systems). Both felt confident that they would be able to troubleshoot in the field as issues arose and this proved to be the case. As the corresponding author went ahead of the rest of the team, he was able to put together a list of supplies that needed to be brought from the U.S. and have Student 2 purchase them. Student 2 and 3 knew ahead of time what parts might give them problems and were able to anticipate some of the issues. Their main concerns were the in-country time constraint and making sure that water was flowing when by the time the team left.

Both Student 2 and Student 3 realized that there would be some level of adaptation that would be necessary in terms of pump construction when the team arrived at the field site. They were effective in working with whatever situation presented itself and moving forward past obstacles, easily made do with what was available to them (for example, building a small platform for the pressure tank out of wood found in the village), and utilized Ghanaian hardware when most appropriate. Student 2 and Student 3 accepted the help that our Ghanaian partners and community members offered and did not try to do everything themselves. Acknowledging community members as experts who could and should contribute, rather than doing it all themselves, not only helped the project progress more efficiently and reduce team fatigue, but worked to build community investment in the project. For example, the community had tradesmen who laid the concrete slab around the pump and splash pad to take excess water away from the pump after consulting with the team on the proper design. The team helped, but for the most part gave the community experts the space to do the work. When giving directions for construction and when putting together the pump components, they took the time to explain (to the best of their ability given the language barrier) to the community what they were doing, how they were doing it, and what the outcome was. It was obvious that there was a mutual respect built between Student 2 and Student 3 and the community members (especially those who were trade-oriented).

\section{Research Staff Member's First-person Reflection:}

Overall, the trip was successful, as clean water was flowing from the pump before the team left Ghana. However, there were certainly obstacles to consider. Language proved to be a significant barrier. The team was supposed to have a translator who spoke both English and Twi present for the majority of the project, but events outside of our control prevented this. For example, one of the country contacts was experiencing some health issues during the time the team was in- 
country and was therefore unable to serve as a translator. Occasionally, the team encountered Ghanaians who spoke some English, but there was no one, consistent translator. This made accomplishing tasks like purchasing supplies much harder and towards the end of trip, the team was feeling pressure to complete the pumping system or risk leaving it unfinished. Frequently, the team had to call one of the in-country contacts who was based two hours away in Kumasi and hand a cellular phone back and forth between a team member and a vendor in Ejura or a community member in Kobriti. The language barrier significantly slowed all processes and many days and hours were spent waiting to move forward. However, it is impossible to guarantee the presence of a translator, even with careful planning, and the team adapted as best as possible to the change in plans.

Another major obstacle was materials. Some of the technical elements were ordered months in advance and kept at the SHI headquarters until the team arrived. Other smaller equipment was brought over with the team, and other materials needed to be sourced locally (concrete, the pump shelter, paint, etc.). Some materials that were brought with the team ended up not working and required the team to go search for replacements, which often did not fit with the American made parts. The village of Kobriti is $\sim 15 \mathrm{~km}$ from the nearest large town of Ejura where these parts were available, thus many days were spent going (or waiting) to go back and forth between the Ejura and Kobriti.

In terms of lessons to take back to the classroom, building in additional material that addresses cultural competency and community building theories, exercises, and expectations would be an important topic to cover. The students said that the DWDW course emphasized points such as utilizing local materials and allowing for a flexible design, however, in general, it is hard to prepare students in the classroom for what might happen in the field. The DWDW course included a workshop where students examined the fully-functioning replica pump that was built on campus, which Student 1 said was helpful in knowing how it was supposed to be put together and look. However, the pumping system was already built before the most recent cohort (of which Students 1 and 2 were) took the class, so the workshop focused on talking about the construction, rather than actual construction). Each student did bring their personal copy of the DWDW textbook though, which they referenced often throughout the trip for information on tasks like design and testing. They even left one book behind for the local tradesmen to use.

One of the most important pieces of a service-learning trip like this is to gather the right team, with a certain personality type and skillset, to implement the project and interact with community partners. Recognizing that the nature of working abroad in a developing nation, far away from the comforts of home, can be taxing on individuals who are not fully prepared to go, adapt, and continually move forward with a positive mindset. This team exhibited positive group dynamics, mutual respect, and worked well together. For this specific trip and project, the presence of two engineering graduate students and an engineering shop staff member who had been to Kobriti before, all with significant engineering design experience, was imperative. Student 1 simply did not have the background to complete this type of project without the expertise of the other team members. While it did not ultimately hinder the success of the project, the corresponding author was unable to be in country at the same time as the rest of the team. He was able to go and return the week before the team left and report back about what to expect, what supplies should be picked up, and reconnected with the community before the team's arrival. While there was a shop staff member who had been to Ghana before who was invaluable in terms of technical ability and some familiarity with the location and contacts, he was not the primary point of contact for the community partners and was not privy to all of the 
in-depth planning for the trip like the corresponding author. It could be assumed that the trip would have gone more smoothly as a whole had the corresponding author been present with the rest of the team.

It cannot confidently be said that the success of the trip was based on the students having taken the DWDW class, as the students explained that most of what they were experiencing on the trip was not a result of having taken the course. However, each student stated the positive impact that the trip had on their worldview and that it helped to reaffirm their chosen engineering career goals. The reaffirmation of these student's goals for working in international development may be one of the main reasons that they all chose to enroll in the DWDW course. Thus, while the students may not have attained intensive skill development as a result of the DWDW course content, the course certainly presented the opportunity for at least a small subset of students to experience firsthand the developing world they are learning to design for. For the rest of the students who are not able to travel and personally work with community partners like Kobriti and SHI, it should be a safe assumption that the DWDW course starts students thinking about sustainable development issues and the range wide of possibilities they will have to contribute in the future.

\section{UI-IESP CRITIQUe, LESSONS LEARNED, AND BEST PRACTICES}

The reflection provided by Student 1 indicated that "DWDW prepared me for living and working in Ghana's Ashanti Region more so than I could have imagined" and "unfortunately, we did not have access to a translator familiar with these types of developments and the various problems and cultural customs associated with this type of work". The student felt the course did all it could or should have done to prepare her for the experience, but the barrier of language made the experience more difficult than anticipated. The research staff member also stated that "language proved to be a significant barrier". But, these individuals both viewed the project as a resounding success if viewed from Kobriti's perspective stating that "clean water was flowing from the pump before the team left Ghana". Clearly the make of the team is a crucial component to success with Student 1 cited as a "rapport builder" and Students $2 \& 3$ and the shop staff person cited as providing most of the technical skills. And, all of the traveling team members made reference to the "life changing" or "perspective shifting" outcome of the trip for them personal. These outcomes, coupled with the safe return of the team and the positive impact on a partner community, represent the overall goals of the UI-IESP.

\section{Critique:}

- The myriad international travel services available at the University of Iowa have made it attractive and convenient for the UI-IESP to become unaffiliated with a national program such as ESW or EWB-USA. The fee and liability structure for EWB-USA and the administrative requirements (that often replicate those of the university) were deemed too onerous by the corresponding author so our student chapter affiliation was ended in 2013. Our student chapter affiliation with ESW was ended in 2011 as the organization transitioned to a new administrative structure. These organizations have much to offer for those considering a program start-up and for those seeking to broaden the scope of their existing program. The corresponding author has encouraged a new departmental faculty 
colleague with interest in such programs to restart an ESW or EWB-USA student chapter at Iowa as a compliment to the UI-IESP.

- The success of the UI-IESP is built upon the impressive work of partners, students and staff. However, it has been sustained over time almost solely by the corresponding author, which leaves the UI-IESP vulnerable to collapse should the corresponding author lose interest or face increased time commitments from research and teaching.

- The scope of the UI-IESP is relatively small in terms of people served internationally. Tens of thousands of dollars have been spent to provide one additional water access point in Kobriti - a community of 600 people. In the Xicotepec, Mexico, era of the UI-IESP, approximately 500 school children gained access to drinking water systems at their schools. These accomplishments are noble. But, clearly the greatest impact has been on the nearly 100 students that have traveled internationally via the UI-IESP and the 185 students that have completed the DWDW course since 2003. Those seeking to start a program will have to define the "communities" they seek to impact at the onset and will have to determine what is considered "success".

- The students that completed the DWDW course and then implemented the well pump project in Kobriti revealed signs of being under prepared. The research staff member cited language as the main project impediment. The language barrier is beyond the scope of the DWDW course, but not beyond the UI-IESP. Arrangements for translators to accompany the summer 2014 team unraveled just prior to arrival in Kobriti. Benjamin Kusi was promoted within SHI approximately two years ago and could not commit to help as he had previously. Arrangements with another translator also did not work out as planned.

- The corresponding author was not in Kobriti concurrently with the implementation team. This was a barrier that was overcome by the shear resiliency of the team members. The corresponding author would have found a new translator, for example. The corresponding author did travel to Kobriti during the week immediately preceding the team implementation to meet with partners and to procure final project supplies that had yet to be staged. This travel arrangement was as a result of scheduling issues and is not a recommended practice. The program leader must remain fully engaged to maximize program success and ensure team safety. A veteran traveler to Kobriti was on the team, but he did not feel fully equipped to ask for needed resources when the time came.

\section{Lessons Learned:}

- The "flipped" DWDW course design and the TILE classroom configuration enables team-based design to occur much more effectively and dynamically. Classroom time is dedicated to designing rather than basic content delivery. To maximize the benefits of this approach for all students, the instructor must explain that the student is ultimately responsible for learning and that the instructor is a curator of learning experiences. The instructor is also an evaluator. Some students may express a feeling of "not getting their money's worth" if the "expert" instructor does not provide at least a few moments of polished lecturing.

- "You don't know if you don't go". This axiom has proven true over and over again. It's a memorable phrase that Student 1 mentioned in her reflection after hearing it in the 
DWDW course. Of course, the students in the DWDW course learn a lot even if they "don't go". But, the students that take the course and then travel as part of the UI-IESP have a much more profound learning experience.

- As a program leader, don't "beat yourself up" too much if participant's reflections indicate a level of under preparedness following a travel experience. Sending a team into an international setting to work with a community and eventually complete projects is a very hard task. You can work on your own and with others to minimize the risks and maximize the preparedness, but there will always be unexpected events and/or issues that will require creative solutions, on the spot.

- Embrace the unknowns and indigenous knowledge that a community brings to a design project. The DWDW course and UI-IESP prepared the students to understand the basic functions and installation requirements of the well pump system, but it did not prescribe a particular design. The pump house and splash pad were designed "on the fly" by the local community with input from SHI and our team. Our backup plan was to build a simple wooden pump house if the community was unable to "come through". The final product ended up being much better that all parties thought was possible and the community will more fully respect and maintain the pump system since they are fully vested.

- Partner with local experts for operation and maintenance of projects. Use local tradesmen to build and install components. These people represent the know-how and the resources needed to make a project as sustainable as possible.

\section{Best Practices:}

- Train students in creative ways using a 3 credit hour course, weekend workshops and resources from ESW and/or EWB-USA. Students should know they are designing with, not for, their developing world partners. Students should mix concrete, lay blocks, use an Abney level, interact with a water pumping system, etc. Students should know not to force Western values onto a community for the sake of a "successful" design. Students should know that their best laid plans will not be implemented exactly as envisioned. Students should know what is "critical" to the function of a design and what is "optional" or "flexible' to the design. Students should know what can be designed or implemented "on the fly" and what cannot. Students should be comfortable with some level of design uncertainty while remaining confident of design safety.

- Use the Field Guide to Environmental Engineering for Development Workers. Give students copies of the book as a reward for great leadership or as a parting gift when they leave for the Peace Corps (they will take it with them - like our team did here - and thank you for it later).

- Partner with a community for the long-term. Schedule follow-up visits to check on previous project performance and to scope out new projects. Take some time to just "hang out" with the community during each trip, if possible. And, stay in regular communication with key project partners even when a trip or new project is not eminent.

- Be sure the community identifies those responsible for the upkeep and maintenance of a system. In Kobriti, a nine member water board has been established with the authority to level fees to generate funds to purchase replacement parts, etc. Also, seek an in-country 
logistics partner (SHI in our case) that has technical expertise and language skills valuable to the projects.

- Utilize the full resources of your university. Partner with your study abroad program on administrative issues related to travel insurance, vaccinations, and cultural competency training. Invite guest speakers from other departments to share insights on international projects that impact communities.

- Partner with your local EWB-USA professional chapter. Students love to travel with professionals and vice versa. This is a great way for students to "interview" with prospective employers while serving a greater good.

- Seek support from your departmental chair and college dean. Make great videos that advertise the impact that projects have on students and international communities. Be respectful and always cast the partner communities in a good light.

- Bring members of your partnering communities to the United States. Benjamin Kusi traveled outside of Ghana for the first time when he visited the University of Iowa in March of 2011. It was transformative for him and for the dozens of students that interacted with him in person.

In a 2009 presentation to the Iowa City Foreign Relations Council titled, To Hell with Good Intentions?: Reflections on the Consequences of "Saving the World"47, the corresponding author publicly questioned the consequences of his actions related to the UI-IESP. The intent was for the UI-IESP and the DWDW course to train students for service-learning and sustainable development in partner communities. There is at least some indication that the UI-IESP and the course simply self-selects for students already pre-disposed for such. But, Student 1 provided evidence that significant, although not complete, training did occur for her in the DWDW course. And, there is a reasonable likelihood that, despite the time spent getting familiar with Kobriti, the water project described here won't turn out to be a sustainable and appropriate use of technology. Future work will involve follow-up in Kobriti which will ultimately determine the degree of success of the project and, ultimately, the UI-IESP.

\section{ACKNOWLEDGMENT}

Thomas Bang, Brandon Barquist, Jeremy Bril, Barry Butler, Tom and Karen Casavant, Christine Catney, Amanda De Hoedt, Kali Feiereisel, Jean Florman, Merry Fredrick, Tracy Just, Brianna Knoll, Benjamin Kusi, Brinn Melody, Jim Mihelcic, Kurt Paterson, Jim Peterson, Nate and Sara Rourke, Michael Schaefer, Hazel Seaba, Luke Smith, Alex VanFossen, Greg Wagner, former DWDW students, former Xicotepec Project students and faculty, the EFELTS Project (Engineering Faculty Engagement in Learning through Service) and the faculty of the Environmental Engineering and Science Graduate Program at the University of Iowa. Funding provided by the Iowa Center for Research by Undergraduates, the University of Iowa Foundation and the College of Engineering. A very special thanks goes to Jerald and Jana Schnoor. 
International Journal for Service Learning in Engineering Special Edition, pp. 300-333, Fall 2014

ISSN 1555-9033

\section{REFERENCES}

1. Zlotkowski, E.; Williams, D., The faculty role in Civic Engagment. Peer Review 2003, 5, (3), 911.

2. Zlotkowski, E. A., In The Case for Service-learning, MacLabhrainn, L. M. I., Ed. Ashgate: England, 2007; pp 37-52.

3. Zlotkowski, E. A., In Civic Education on the Rocks?, Hartley, J. S. M., Ed. Temple University Press: Philadelphia, PA, 2011; p 29.

4. Zlotkowski, E. A.; Saltmarsh, J., Higher Education and Democracy: Collected Essays on Servicelearning and Civic Engagement. Temple University Press: Philadelphia, PA, 2011.

5. Zlotkowski, E. A.; Duffy, D. K., In Two Decades of Community-Based Learning, Wehlburg, M. S. C., Ed. Jossey-Bass: San Francisco, 2011; p 15.

6. $\quad$ Cornejo, P. K.; Zhang, Q.; Mihelcic, J. R., Quantifying benefits of resource recovery from sanitation provision in a developing world setting. Journal of Environmental Management 2013, $131,7-15$.

7. Gadgil, A.; Fridley, D.; Zheng, N.; Sosler, A.; Kirchstetter, T.; Phadke, A., Energy in the Developing World. AIP Conference Proceedings 2011, 1401, (1), 54-74.

8. Gindling, T. H.; Newhouse, D., Self-Employment in the Developing World. World Development 2014, 56, 313-331.

9. Kremer, M.; Brannen, C.; Glennerster, R., The Challenge of Education and Learning in the Developing World. Science 2013, 340, (6130), 297-300.

10. McMichael, P.; Schneider, M., Food Security Politics and the Millennium Development Goals. Third World Quarterly 2011, 32, (1), 119-139.

11. Murphy, H. M.; McBean, E. A.; Farahbakhsh, K., Appropriate Technology - A Comprehensive Approach for Water and Sanitation in the Developing World. Technology in Society 2009, 31, (2), 158-167.

12. Poku, N. K.; Whitman, J., The Millennium Development Goals and Development after 2015. Third World Quarterly 2011, 32, (1), 181-198.

13. Ravallion, M., Income inequality in the developing world. Science 2014, 344, (6186), 851-855.

14. Sachs, J. D., Health in the Developing World: Achieving the Millennium Development Goals. World Health Organization. Bulletin of the World Health Organization 2004, 82, (12), 947-9; discussion 950-2.

15. Sauer, M.; Smith, S.; Clemens, B., Does it Pay to Invest in Potable Water in the Developing World? Relationships Between External Financing and Economic Development in Sustainable Community-run Integrated Projects. Journal of International Development 2012.

16. Sobsey, M. D.; Stauber, C. E.; Casanova, L. M.; Brown, J. M.; Elliott, M. A., Point of Use Household Drinking Water Filtration: A Practical, Effective Solution for Providing Sustained Access to Safe Drinking Water in the Developing World. Environmental Science \& Technology 2008, 42, (12), 4261-4267.

17. Wolfram, C.; Shelef, O.; Gertler, P., How Will Energy Demand Develop in the Developing World? Journal of Economic Perspectives 2012, 26, (1), 119-138.

18. Yoder, F. Sustainability at Iowa. http://sustainability.uiowa.edu/teaching-research/certificate/ (accessed December 12, 2014).

19. Florman, J. C.; Just, C.; Naka, T.; Peterson, J.; Seaba, H. H., Bridging the Distance: Service Learning in International Perspective. New Directions for Teaching and Learning 2009, (118), 71-84.

20. The Xicotepec Project. https://www.facebook.com/xicoproj (accessed December 12, 2014).

21. University of Iowa, EPA P3 Award: Design and Testing of a Point of Use Electrolytic Chlorine Generator for Drinking Water Disinfection in Poor Countries.

http://cfpub.epa.gov/ncer_abstracts/index.cfm/fuseaction/display.abstractDetail/abstract/8626/rep ort/0 (accessed December 12, 2014). 
22. Self-Help International. http://www.selfhelpinternational.org/ (accessed December 12, 2014).

23. UNESCO Small is Working Video.

http://www.unesco.org/archives/multimedia/index.php?s=films_details\&pg=33\&id=562\#.VBHV 5mOEw24 (accessed December 12, 2014).

24. Introductory Engineering Design: A Projects-Based Approach. http://itll.colorado.edu/courses_workshops/geen_1400/resources/textbook/ (accessed December 12, 2014)

25. The Millennium Development Goals Report. http://mdgs.un.org/unsd/mdg/Resources/Static/Products/Progress2006/MDGReport2006.pdf (accessed December 12, 2014).

26. Practical Action. http://practicalaction.org/ (accessed December 12, 2014).

27. University of Iowa TILE Classrooms. http://tile.uiowa.edu/ (accessed December 12, 2014).

28. Mihelcic, J. R., Field Guide to Environmental Engineering for Development Workers: Water, Sanitation, and Indoor Air. American Society of Civil Engineers: 2009.

29. Inside the Flipped Classroom. In NEXT: The Future of Higher Education; Special Reports, 2013.

30. Bergmann, J.; Sams, A., Flip Your Classroom : Reach Every Student in Every Class Every Day. ISTE: Eugene, OR, USA, 2012.

31. Bull, G.; Ferster, B.; Kjellstrom, W., Inventing the Flipped Classroom. Learning \& Leading with Technology 2012, 40, (1), 10-11.

32. Ballentine, B., Desire2Learn for Higher Education Cookbook. Packt Publishing: Olton, Birmingham, GBR, 2012.

33. Reinvent the Toilet Challenge. http://www.gatesfoundation.org/What-We-Do/GlobalDevelopment/Reinvent-the-Toilet-Challenge (accessed December 12, 2014).

34. Iowa Student Engineers Develop Hand-held Water Sanitizer for a Thirsty World. http://www.eurekalert.org/pub_releases/2009-02/uoi-ise020909.php (accessed December 12, 2014).

35. Five Weeks in Ghana (YouTube video). http://www.youtube.com/watch?v=c4KvpOBFYWw (accessed December 12, 2014).

36. Paterson, K. G. F., Valerie Development for the Other 80\%: Engineering Hope. http://ww2.cs.mu.oz.au/aaee2007/papers/paper_02.pdf (accessed December 12, 2014).

37. Richards-Kortum, R., Biomedical Engineering for Global Health. Cambridge University Press: 2010.

38. Center for Innovation in Global Health Technologies. http://www.cight.northwestern.edu/ (accessed December 12, 2014).

39. Erzberger, C.; Prein, G., Triangulation: Validity and Empirically-based Hypothesis Construction. Quality and Quantity 1997, 31, (2), 141-154.

40. Lincoln, Y. S. Guba, E. G. , Naturalistic inquiry. Sage Publications: Beverly Hills, CA, 1985.

41. Farmer, T.; Robinson, K.; Elliott, S. J.; Eyles, J., Developing and Implementing a Triangulation Protocol for Qualitative Health Research. Qualitative Health Research 2006, 16, (3), 377-394.

42. Bernard, H. R., Research Methods in Anthropology: Qualitative and Quantitative Approaches. Sage Publications: London, 2006.

43. Creswell, J. W., Qualitative Inquiry and Research Design: Choosing Among Five Traditions. Sage Publications: 1998.

44. Green, J.; Thorogood, N., Qualitative Methods for Health Research. SAGE Publications: 2004.

45. Charmaz, K., Constructing Grounded Theory: A Practical Guide Through Qualitative Analysis. SAGE Publications: 2006.

46. Pure Home Water: AfriClay Filter. http://purehomewater.org/the-africlay-filter/ (accessed December 12, 2014).

47. Just, C. To Hell with Good Intentions?: Reflections on the Consequences of "Saving the World". http://digital.lib.uiowa.edu/cdm/ref/collection/icfrc/id/129 (accessed December 12, 2014). 


\title{
APPENDiX A: 2007 DWDW COURSE SYllabuS \\ 53:141: Design for the Developing World
}

Fall 2007

Mondays and Wednesdays 4:30-5:45pm

3321 Seamans Center

\author{
Instructor: $\quad$ Craig Just, Civil and Environmental Engineering \\ Office: 4111 Seamans Center \\ Phone: 319-335-5051 \\ Email: craig-just@uiowa.edu
}

Office Hours: Nearly "unlimited" access by appointment - I want to meet with you.

Required Texts: None.

Expenses: An online personality assessment (\$26.95) is required and some relatively inexpensive project supplies may be purchased (up to $\$ 25$ for the solar oven, etc.)

Description: (3 Credit Hours): This course provides students the opportunity to work in interdisciplinary teams to propose solutions to problems people face in the "developing world". Students will interact with local community partners to explore the service-learning objectives designed into the course. Appropriate technologies to improve water and sanitation, energy, housing, and health will be studied and developed. Community building strategies, participatory methods and other techniques essential to a good design will be explored.

\section{Design:}

This course was designed intentionally using four basic principles inherent to organizing and constructing a service-learning course.

1. Engagement: Does the service component meet a public good? How do you know this? Has the community been consulted? How? How have campus-community boundaries been negotiated and how will they be crossed?

2. Reflection: Is there a mechanism that encourages students to link their service experience to course content and to reflect upon why the service is important?

3. Reciprocity: Is reciprocity evident in the service component? How? "Reciprocity suggests that every individual, organization, and entity involved in the service-learning functions as both a teacher and a learner. Participants are perceived as colleagues, not as servers and clients".

4. Public Dissemination: Is service work presented to the public or made an opportunity for the community to enter into a public dialogue? For example: Is the data students collect on the saturation of toxins in the local river made public? How? To whose advantage? 
Students work with service partners to understand a particular community problem or need. This partnership presumes that the students have some knowledge they can draw upon to make recommendations to the community or develop a solution to the problem.

A challenge particular to this service-learning course is that the objectives are based in using technology to reduce poverty in poor countries while partnering with community organizations in a rich country (the USA). Inherent to service-learning is that the community engagement experiences are closely linked to course content. But, if course content involves discussions about the design of composting latrines for use in Haiti, for example, it can be challenging to find a local partnering experience that enhances concepts discussed in class related to composting latrines.

\section{Learning Goals:}

1. Course specific: understand appropriate technology, understand capacity building, understand and implement the design process

2. Generic academic: critical thinking, problem-solving.

3. Learning capacity: become an active learner, become an independent learner, learning how to extract meaning from experience, learning how to apply academic knowledge in the "real-world", learning to integrate theory and experience, learning across disciplines.

4. Community: poverty, health, homelessness, immigrant needs, etc.

5. Inter- and Intra-Personal: learning how to work collaboratively with others, learning about other groups and cultures, exploring personal values, ethics and ideology, learning about self, strengthening personal skills, developing a sense of appreciation, awe, and/or wonder.

Peer Review: An important learning objective of this course is to improve self-awareness and abilities to collaborate with "internal" teammates and "external" partners. Students will evaluate themselves and will be reviewed by classmates and the service learning partners associated with the class.

Assignments: Assignments are divided into personal and team activities and might be a paper exercise and/or a project. Assignments are usually due on Wednesdays before the start of class - typically typed and posted to the ICON site.

\section{Point Breakdown:}

$\begin{array}{lc}\begin{array}{l}\text { Semester-long Team Design Assignments (TD1, TD2, etc.) } \\ \quad \text { "Design and Testing of a Point of Use Electrolytic }\end{array} & 200 \\ \quad \text { Chlorine Generator for Drinking Water Disinfection in } & \\ \quad \text { Poor Countries” } & 150 \\ \text { Short-term Team Projects (P1, P2, etc. - 3@50 points each) } & 100 \\ \text { Three-part Reflections Summaries (RS1, RS2, etc. - 5@20 points each) } & 75 \\ \text { Personal Assignments (A1, A2, etc. - 15@5 points each) } & 60 \\ \text { Quizzes (Q1, Q2, etc. -6@10 points each) } & 50 \\ \text { Strength of Service Learning Activities } & 50 \\ \text { Peer Review (R1, R2, etc. - 5@10 points each) } & 685 \\ \text { TOTAL } & \end{array}$


International Journal for Service Learning in Engineering Special Edition, pp. 300-333, Fall 2014

ISSN 1555-9033

Grading:

A standard percentage scale will be used as shown from the ICON site image below.

\begin{tabular}{|c|c|c|c|c|c|}
\hline$\#$ & Symbol & Start (\%) & Assigned Value (\%) & Colour & \\
\hline 1 & $\mathrm{~F}$ & 0 & 59.99 & Red & $\checkmark$ \\
\hline 2 & D- & 60 & 62.99 & Orange & $\checkmark$ \\
\hline 3 & D & 63 & 66.99 & Orange & $\checkmark$ \\
\hline 4 & $\mathrm{D}+$ & 67 & 69.99 & Orange & $\checkmark$ \\
\hline 5 & C- & 70 & 72.99 & Yellow & $\checkmark$ \\
\hline 6 & C & 73 & 76.99 & Yellow & $\checkmark$ \\
\hline 7 & $\mathrm{C}+$ & 77 & 79.99 & Yellow & $v$ \\
\hline 8 & B- & 80 & 82.99 & Green & $\checkmark$ \\
\hline 9 & B & 83 & 86.99 & Green & $\checkmark$ \\
\hline 10 & $\mathrm{~B}+$ & 87 & 89.99 & Green & $\checkmark$ \\
\hline 11 & A- & 90 & 92.99 & Blue & $\checkmark$ \\
\hline 12 & A & 93 & 100 & Blue & $\checkmark$ \\
\hline
\end{tabular}


International Journal for Service Learning in Engineering Special Edition, pp. 300-333, Fall 2014

ISSN 1555-9033

Timeline:

(TD = Team Design; $\mathrm{P}=$ Project - Short Term; $\mathrm{A}=$ Personal Assignment; $\mathrm{RS}=$ Reflections Summary)

\begin{tabular}{|c|c|c|c|c|}
\hline $\begin{array}{l}\text { Aug } 27 \\
\text { Aug } 29\end{array}$ & $\begin{array}{l}\text { Week 1: Welcome and Introduction } \\
\text { Intermediate Technologies - Solar Cooking }\end{array}$ & $\begin{array}{l}\text { Assignments } \\
\text { Given }\end{array}$ & $\begin{array}{l}\text { Due } \\
\text { (W) }\end{array}$ & Quiz \\
\hline & $\begin{array}{l}\text { Small is Working Video and Booklet; UI Engineers for a Sustainable World past and present; } \\
\text { Introduction to Engineering Design (IED) Manual; Millennium Development Goals; Service } \\
\text { Learning Concepts and Opportunities; Introduction to semester-long team design project; } \\
\text { Assignment of first short-term project (P1: solar cooking oven) } \\
\text { Resources: U of I Civic Engagement Program: } \underline{\text { http://www. uiowa.edu/ cep/ }} \\
\text { Corridor Volunteers: http://www.corridorvolunteers.org } \\
\quad \text { Engineers Without Borders: } \underline{\text { http://www.ewb-usa.org }} \\
\text { lowa Valley Habitat for Humanity: } \underline{\text { http://www.ivhfh.org/index.php }} \\
\text { Assigned Reading: IED Ch. 1, 3, 6; Electrolytic chlorine generator proposal } \\
\text { NOTES: }\end{array}$ & $\begin{array}{l}\text { A1 } \\
\text { A2 } \\
\text { P1a } \\
\text { TDa }\end{array}$ & A1 & No \\
\hline \multirow[t]{2}{*}{$\begin{array}{l}\text { Sep } 3 \\
\text { Sep } 5\end{array}$} & $\begin{array}{l}\text { Week 2: No Class September } 3 \text { - Labor Day } \\
\quad \text { No Class September } 5 \text { - attend "alternative events" listed below }\end{array}$ & $\begin{array}{l}\text { Assignments } \\
\text { Given }\end{array}$ & $\begin{array}{l}\text { Due } \\
\text { (W) }\end{array}$ & Quiz \\
\hline & $\begin{array}{l}\text { Alternative Events: (1) Volunteer Fair http://www.uiowa.edu/ cep/ } \\
\text { Main Lounge, IMU, Sep 5, noon - 4pm. } \\
\text { (2) UI Energy EXPO http://energy.uiowa.edu/2007/index.htm } \\
\text { Old Capital Mall, Pentacrest, 9am - 5pm. } \\
\text { LIVE MUSIC, Public Property, 7pm - 9pm. }\end{array}$ & A3 & & No \\
\hline \multirow[t]{2}{*}{$\begin{array}{l}\text { Sep } 10 \\
\text { Sep } 12\end{array}$} & $\begin{array}{c}\text { Week 3: Intermediate Technologies - Water and Sanitation } \\
\text { Continued Team Building, Prototyping Process }\end{array}$ & $\begin{array}{l}\text { Assignments } \\
\text { Given }\end{array}$ & $\begin{array}{l}\text { Due } \\
\text { (W) }\end{array}$ & Quiz \\
\hline & $\begin{array}{l}\text { Waterborne human illness; Global issues; Drinking water treatment and safe storage; } \\
\text { Rainwater harvesting; PuR packet demonstration; chemical and biological water analysis; } \\
\text { chlorine chemistry; electrolysis; sanitation, etc. } \\
\text { P1 activities: Build solar cooking ovens during class time Sep } 12 \text { (room 1246SC). } \\
\text { RS activities: Everybody should serve at a Habitat for Humanity site in September (RS1) } \\
\text { NOTES: }\end{array}$ & $\begin{array}{c}\text { A4 } \\
\text { TDb }\end{array}$ & $\begin{array}{l}\text { A3 } \\
\text { TDa } \\
\text { P1a }\end{array}$ & Q1 \\
\hline \multirow[t]{2}{*}{$\begin{array}{l}\text { Sep } 17 \\
\text { Sep } 19\end{array}$} & Week 4: Intermediate Technologies - Water and Sanitation & $\begin{array}{l}\text { Assignments } \\
\text { Given }\end{array}$ & $\begin{array}{l}\text { Due } \\
\text { (W) }\end{array}$ & Quiz \\
\hline & $\begin{array}{l}\text { Topics Continued } \\
\text { P1 activities: Solar cook-off Sep } 19 \text { on the rooftop terrace or John Deere Plaza } \\
\text { NOTES: }\end{array}$ & $\begin{array}{l}\text { A5 } \\
\text { TDc }\end{array}$ & $\begin{array}{l}\text { A4 } \\
\text { TDb } \\
\text { P1b }\end{array}$ & No \\
\hline \multirow[t]{2}{*}{$\begin{array}{l}\text { Sep } 24 \\
\text { Sep } 26\end{array}$} & Week 5: Intermediate Technologies - Shelter & $\begin{array}{l}\text { Assignments } \\
\text { Given }\end{array}$ & $\begin{array}{l}\text { Due } \\
\text { (W) }\end{array}$ & Quiz \\
\hline & $\begin{array}{l}\text { Global statistics; Construction techniques; Indoor air quality; Habitat for Humanity; Refugee } \\
\text { camps; Hexayurt shelters } \\
\text { Assignment of second short-term project (P2: sand filtration and disinfection of drinking water) } \\
\text { P1 activities: Final report DUE. } \\
\text { TD activities: First progress report (TDc) DUE. } \\
\text { NOTES: }\end{array}$ & $\begin{array}{l}\text { A6 } \\
\text { P2a } \\
\text { TDd }\end{array}$ & $\begin{array}{c}\text { A5 } \\
\text { TDc } \\
\text { P1c }\end{array}$ & Q2 \\
\hline \multirow[t]{2}{*}{$\begin{array}{l}\text { Oct } 1 \\
\text { Oct } 3\end{array}$} & Week 6: Intermediate Technologies - Water and Sanitation & $\begin{array}{l}\text { Assignments } \\
\text { Given }\end{array}$ & $\begin{array}{l}\text { Due } \\
\text { (W) }\end{array}$ & Quiz \\
\hline & $\begin{array}{l}\text { Water testing (chlorine, bacteria, turbidity, etc.); biosand filters (design, construction, } \\
\text { effectiveness); Water and Public Health; Waterborne infection cycle } \\
\text { P2 activities: First four steps of the design loop }\end{array}$ & $\begin{array}{l}\text { A7 } \\
\text { TDe } \\
\text { P2b }\end{array}$ & $\begin{array}{l}\text { A6 } \\
\text { TDd } \\
\text { P2a } \\
\text { RS1 }\end{array}$ & No \\
\hline
\end{tabular}


International Journal for Service Learning in Engineering Special Edition, pp. 300-333, Fall 2014

ISSN 1555-9033

RS activities: First reflections summary (RS1) DUE. Habitat for Humanity Build or other.

R1

Peer Review Due (R1) - take ICON Survey

Oct 8

Week 7: Intermediate Technologies - Water and Sanitation

Oct 10

Composting latrines; Waterborne infection cycle again

P2 activities: All steps of the design loop.

A8

Due

$(\mathrm{W})$

TDf TDe

P2c P2b

Oct 15

Oct 17

Week 8: Intermediate Technologies - Shelter

Topics Continued

P2 activities: FINAL water purification project report due.

RS activities: Second reflections summary (RS2) DUE. Habitat for Humanity Build, etc.

TD activities: Second progress report (TDf) DUE

Peer Review Due (R2) - take ICON Survey

Week 9: Intermediate Technologies - Energy

NOTE: Oct. 22 Team Meetings; Oct. 24 Discussion

Assignments Due

Given (W)

A9

A8

TDg

Biogas and liquid biofuels; micro-hydropower; solar; wind; biomass; refrigeration

TD activities: Work on Team Design project on Oct 22 while instructor is away.

TDh

Due

Oct 27 is Make a Difference Day - your service for the UI project could be your third reflections summary focus.

NOTES:

Week 10: Intermediate Technologies - Energy

Topics Continued

P3 activities: First four steps of the design loop.

RS activities: Third reflections summary (RS3) DUE. Make a Difference Day.

\begin{tabular}{|c|c|}
\hline \multirow{2}{*}{$\begin{array}{l}\text { Nov } 5 \\
\text { Nov } 7\end{array}$} & Week 11: Information and Communication Technology \\
\hline & $\begin{array}{l}\text { Wireless communications; eGranary; Appropedia } \\
\text { P3 activities: All steps of the design loop. } \\
\text { NOTES: }\end{array}$ \\
\hline \multirow{2}{*}{$\begin{array}{l}\text { Nov } 12 \\
\text { Nov } 14\end{array}$} & Week 12: Intermediate Technologies - Agriculture \\
\hline & $\begin{array}{l}\text { Microirrigation; composting; soil fertility; sand dams; water harvesting; coffee } \\
\text { P3 activities: FINAL hexayurt shelter report due } \\
\text { RS activities: Fourth reflections summary (RS4) DUE. Habitat for Humanity, etc. } \\
\text { TD activities: Third progress report; First poster draft; First PowerPoint draft (TDj) DUE } \\
\text { November 11-17 is National Hunger and Homelessness Awareness Week } \\
\text { Peer Review Due (R3) - take ICON Survey }\end{array}$ \\
\hline
\end{tabular}

\begin{tabular}{l|l|}
$\begin{array}{l}\text { Nov } 19 \\
\text { Nov } 21\end{array}$ & $\begin{array}{l}\text { Week 13: NO CLASSES } \\
\text { No Classes - Thanksgiving Break }\end{array}$ \\
\hline & No Activities \\
\hline Nov 26 & Week 14:Intermediate Technologies - Manufacturing and Recycling \\
Nov 28 &
\end{tabular}

\begin{tabular}{|c|c|c|}
$\begin{array}{c}\text { Assignments } \\
\text { Given }\end{array}$ & $\begin{array}{c}\text { Due } \\
\text { (W) }\end{array}$ & Quiz \\
\hline No & No & No \\
\hline $\begin{array}{c}\text { Assignments } \\
\text { Given }\end{array}$ & $\begin{array}{c}\text { Due } \\
\text { (W) }\end{array}$ & Quiz \\
\hline
\end{tabular}

Paper; Aluminum; Collection techniques

\begin{tabular}{|c|c|}
$\begin{array}{c}\text { Assignments } \\
\text { Given }\end{array}$ & $\begin{array}{c}\text { Due } \\
\text { (W) }\end{array}$ \\
\hline A11 & A10 \\
\hline TDi & TDh \\
P3b & RS3 \\
& P3a \\
\hline
\end{tabular}

RS activities: Fifth reflections summary (RS5) DUE. Habitat for Humanity, etc. 


\begin{tabular}{|c|c|c|c|c|}
\hline \multirow[t]{2}{*}{$\begin{array}{l}\text { Dec } 10 \\
\text { Dec } 12\end{array}$} & Week 16: Course Wrap-up & $\begin{array}{l}\text { Assignments } \\
\text { Given }\end{array}$ & $\begin{array}{l}\text { Due } \\
\text { (W) }\end{array}$ & Quiz \\
\hline & $\begin{array}{l}\text { Open } \\
\text { TD activities: Final report; Final poster; Final PowerPoint (TDn) DUE } \\
\text { Peer Review Due (R4) - take ICON Survey (worth } 20 \text { points instead of 10) }\end{array}$ & no & $\begin{array}{l}\text { A15 } \\
\text { TDn } \\
\text { R4 }\end{array}$ & No \\
\hline \multirow[t]{2}{*}{ Dec 17} & $\begin{array}{l}\text { Week } 17 \\
\text { Comprehensive Exam }\end{array}$ & & & \\
\hline & No comprehensive exam - Final Presentations & & & \\
\hline
\end{tabular}

\section{Three Part Reflection Summaries:}

The purpose of the three-part reflection notebook is to allow you to turn your community-based experiences into substantive learning. To do this effectively, you must be careful to differentiate among three kinds of responses: objective accuracy, personal awareness, and intellectual analysis. You should make a journal entry after every community visit or major service task and then submit your notes electronically at intervals noted in the course timeline. Write the three parts as follows:

- PART ONE (normal font): an objective, detailed description of what you did. Your description should be organized in 10 minutes segments. If you find yourself simply saying more of the same, you're not being sufficiently specific and may not have paid careful enough attention to what was going on. Grading criteria for this section are (1) amount of useful detail, and (2) degree of objectivity;

- PART TWO (bold font): a self-critical response to your visit, including feelings and thoughts judgments and what you can learn about yourself and your assumptions from what you did and how you reacted. This section is particularly concerned with discoveries you make about yourself and your attitudes toward other people you encounter in the course of your community-based work. The grading criteria for this section are still in self-analysis and demonstrated self-awareness -- not just what but why; not just how you react to that how you evaluate your reactions and what you can learn from them;

- PART THREE (italics font): a discussion of your experiences in terms of concepts and themes discussed in class and/or class readings. This section should contain no narrative, and very little subjective reaction. Instead it should demonstrate your skill in making connections between community-based experiences and class concerns as well as your skill in using concepts discussed in class to analyze and illuminate your community-based experiences. Grading criteria for this section are skill in using course concepts to interpret community experiences and ability to use community experiences to illustrate or challenge course concepts.

All journal entries should be double-spaced and dated. There is no required length, but anything less than half a page each for parts one and two, and $2 / 3$ of the page for part three may well be short or underdeveloped and considered average ( $\mathrm{C}$ grade) work.

\section{Strength of Service Learning Activities:}

Students are to have at least 5 , independent service learning activities to reflect upon throughout the course of the semester. There are 50 points available to students for "strength of the service learning activities" and these points will be awarded as follows: Average work consists of 5, one-hour experiences of varying quality (20-29 points); Above average work consists of 5, two-hour experiences of varying quality (30-39 points); Excellent work consists of 5 or more, three-hour experiences of varying quality (40-50 points). 


\section{APPENDIX B: 2013 DWDW COURSE SYLlabUS 053:141 Design WITH the Developing World}

Spring 2013

Wednesday, 6:30 - 9:00 p.m.

1022 Main Library and Hydraulics East Annex

Facilitator: $\quad$ Craig Just, Civil and Environmental Engineering

Office: 4111 Seamans Center

Phone: 319-335-5051

Email: craig-just@uiowa.edu

Wednesdays, 1 p.m. - 5 p.m. and by appointment. Always let me know in advance when you plan to visit me so I can be sure to be there.

Required Books: Field Guide to Environmental Engineering for Development Workers by James Mihelcic.

Description: This course provides students the opportunity to work in interdisciplinary teams to propose solutions to problems people face in the "developing world". Appropriate technologies to improve water and sanitation, energy, housing, and health are studied and developed. Community building strategies, participatory methods and other techniques essential to a good design are explored.

Outcomes: $\quad$ 1. Ability to apply math, science and engineering to problems of the developing world.

2. Ability to design and conduct experiments and to analyze and interpret results.

3. Ability to design systems, components, or processes to meet specified objectives.

4. Ability to work as members/leaders of multidisciplinary project and/or research teams.

5. Ability to identify, formulate and solve engineering problems.

6. Understanding of professional and ethical responsibilities and usefulness of peer support.

7. Ability to communicate effectively in written, oral, and graphical forms.

8. Awareness of world diversity, culture and global engineering impact.

9. Awareness of value of lifelong learning.

10. Understanding role of civil and environmental engineering for physical infrastructure.

11. Ability to use the principles, skills and modern tools for successful engineering practice and research. 
Assignments: Individual and team-oriented assignments are utilized in this course. Assignments are usually due on Wednesdays before the start of class typically typed and posted to the course ICON site.

Individual assignments should reflect the work of individual students without any hint of plagiarism even if assignments are completed in a group setting. Students caught cheating on individual work will receive a warning on the first offense; they will lose all individual assignment points for the entire semester on the second offense; a third offense may lead to dismissal from the course.

Team assignments can be uploaded to ICON by any member of the team, on behalf of the entire team.

Peer Learning: Much of the learning in this course is facilitated through teamwork and peerto-peer dialogue and activities as guided by your course facilitator. Successful peer-to-peer interactions require practice, planning, patience and "give and take". Begin to build your team relations right away to get the most out of the course. Please rely on your teammates for notes, announcements, etc., for any class periods missed, but please make the course facilitator aware of planned absences before class and emergency absences as soon as practical.

Teams will be assigned by the course instructor with considerations for creating diverse teams with respect to major, year in school, developing world experience, gender, etc.

Points: $\quad$ Online Quizzes (6 total) 120

Individual Class Participation and Preparedness $\quad 120$

Individual Performance on Workshops 120

Team Preparation and Implementation 120

Team Toilet Challenge and Workshop Results 120

Grading: A standard percentage scale will be used as shown:
A: 93-100;
A-: 90-92.99
$\mathrm{B}+:$ 87-89.99;
B: 83-86.99;
B-: 80-82.99
C+: 77-79.99;
C: 73-76.99;
C-: 70-72:99
$D+:$ 67-69.99;
D: 63-66.99;
D-: 60-62.99
F: $<59.99$

Accommodations for Students with Disabilities: I would like to hear from anyone who has a disability which may require seating modifications or testing accommodations or 
accommodations of other class requirements, so that appropriate arrangements may be made. Please contact me during my office hours.

Electronic Communications: Email and ICON will be utilized for student contact with the expectation that students login and check these resources at least once each day the class meets. University policy specifies that students are responsible for all official correspondence sent to their standard University of lowa e-mail address (@uiowa.edu).

Academic Misconduct: The College of Engineering endorses the policies and rights of students as printed in Section 1 of the General Conduct Regulations in the University of lowa, Code of Student Life. The College of Engineering reserves the authority to handle acts of academic misconduct as adopted by Engineering Faculty and Staff.

http://www.engineering.uiowa.edu/ess/current-students/academic-policies-

standards/academic-misconduct

Illnesses: Faculty cannot require a doctor's note from a student who is requesting an excused absence from class due to illness; students should self-report illnesses using the form on the Registrar's website.

http://www.registrar.uiowa.edu/Student/FormsforStudents/tabid/79/Default.aspx

You cannot be penalized for missing a class due to illness (this includes attendance requirements, assignments, quizzes and tests). You will be provided appropriate makeup work if you have excused absences. It is the experience of Student Health that very few students take advantage of faculty by lying about sicknesses. Lying about sickness is a violation of the Code of Student Life and the University could impose penalties on a student that is caught lying.

Workshops: Almost half of the course will take place at the Hydraulics East Annex. We will always enter at the south door of that building. This is shop area with a lot of equipment and tools so safety precautions will be emphasized. Wear pants and close-toed shoes at all times. Your clothes and shoes will get dirty. Long hair should be pulled back and secured. Gloves and eye protection will be provided. 


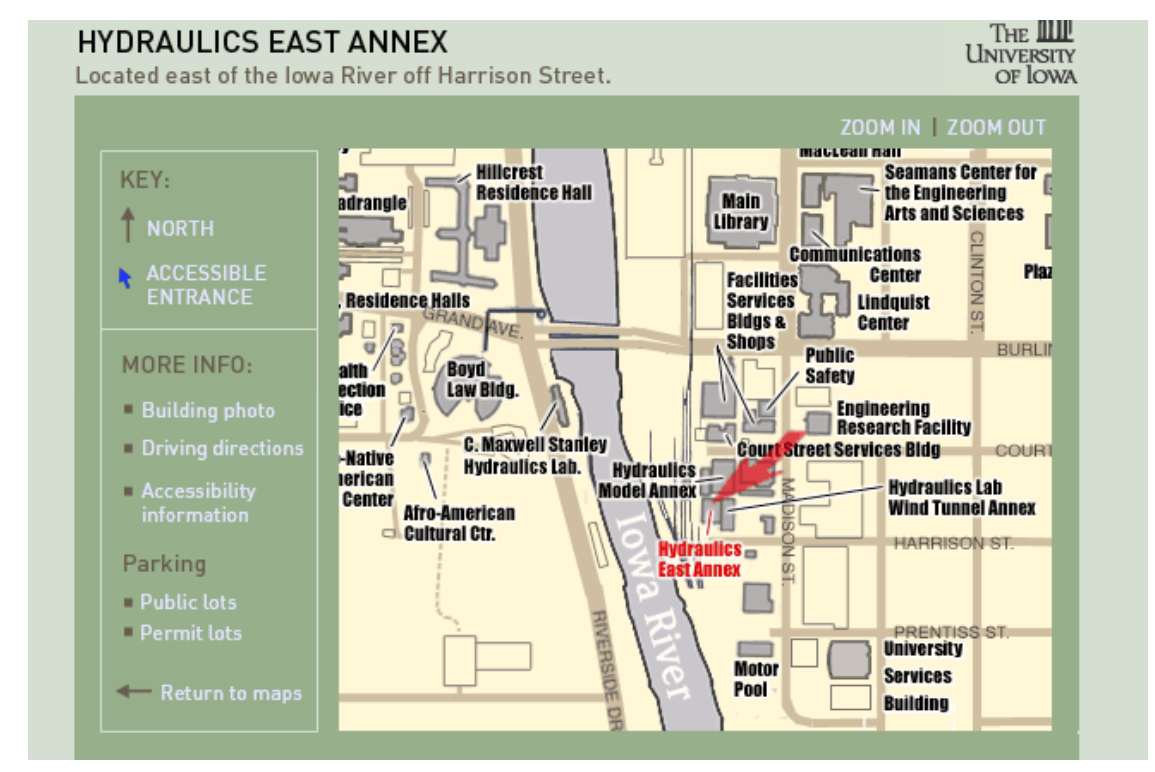

Electronic Devices in the Classroom: Use of electronic devices such as laptops, cell phones, iPads, etc. in the classroom is encouraged only as a means to search for knowledge related to the course. Students are encouraged to bring their personal electronic devices if they will enhance learning.

Non-participatory activities, such as texting for personal reasons or checking social networking sites for personal entertainment, are strongly discouraged. Students caught engaging in these activities during class will likely find the subsequent dialogue with the course facilitator uncomfortable and the consequences may also be undesirable. The course facilitator reserves the right lower a student's grade based on documented occurrences of such activity.

A basic calculator, with scientific notation capabilities, is required and can be used in the classroom at any time.

NOTE: We will use Trimble SketchUp 3D design software in the course and it free to download to any computer. Install this software on your laptop and bring it to class if you are willing. 
International Journal for Service Learning in Engineering Special Edition, pp. 300-333, Fall 2014

ISSN 1555-9033

\section{Timeline:}

\begin{tabular}{|c|c|}
\hline \multirow[t]{2}{*}{ Jan 23} & Week 1: Field Guide Chapters 1-4 \\
\hline & $\begin{array}{l}\text { Introduction; Community Approaches to Project Design and Management } \\
\text { There may be in-class assignments at any point throughout the semester. Scores will count toward your class participation and } \\
\text { preparation points. }\end{array}$ \\
\hline \multirow[t]{2}{*}{ Jan 30} & Week 2: Field Guide Chapters 5-8 \\
\hline & $\begin{array}{l}\text { Basics of Construction } \\
\text { DUE before class time: Online Quiz } 1 \text { covering Chapters 1-4. }\end{array}$ \\
\hline \multirow[t]{2}{*}{ Feb 6} & Week 3: Field Guide Sections 9-13 \\
\hline & $\begin{array}{l}\text { Water Supply and Treatment } \\
\text { DUE before class time: Online Quiz } 2 \\
\text { We will visit the warehouse (Hydraulics East Annex) where the workshops will be held during class. This is a two block walk } \\
\text { from our class room. Dress accordingly for the weather. }\end{array}$ \\
\hline \multirow[t]{2}{*}{ Feb 13} & Week 4: Field Guide Sections 14-18 \\
\hline & $\begin{array}{l}\text { Water Supply and Treatment } \\
\text { DUE before class time: Online Quiz } 3 \\
\text { We will have a tutorial on Trimble SketchUp software in class. Learn as much as you can before class though. }\end{array}$ \\
\hline \multirow[t]{2}{*}{ Feb20 } & Week 5: Field Guide Sections $19-23$ \\
\hline & $\begin{array}{l}\text { Wastewater Treatment } \\
\text { DUE before class time: Online Quiz } 4 \\
\text { DUE: Preliminary Reinvent the Toilet Challenge Team Presentation. Teams will present in class. } \\
\text { DUE: First-draft Reinvent the Toilet Team Proposal } \\
\text { DUE: First-draft of team World Water Day Poster. } 2 \mathrm{ft} \text { by } 3 \mathrm{ft} \text { vertical layout. }\end{array}$ \\
\hline \multirow[t]{2}{*}{ Feb 27} & Week 6: Field Guide Sections 24-25 \\
\hline & $\begin{array}{l}\text { Solid Waste; Air Quality } \\
\text { DUE before class time: Online Quiz } 5 \\
\text { DUE: First draft of the learning materials for the workshop your team will facilitate. Teams will present in class. }\end{array}$ \\
\hline \multirow[t]{2}{*}{ Mar 6} & Week 7: Workshop Preparation \\
\hline & $\begin{array}{l}\text { DUE before class time: Online Quiz } 6 \\
\text { Meet at the Hydraulics East Annex. Enter through the south door, nearest the UI Motor Pool parking lot. }\end{array}$ \\
\hline \multirow[t]{2}{*}{ Mar 13} & Week 8: Team Presentations and Individual Assignments \\
\hline & $\begin{array}{l}\text { Reinvent the Toilet presentations will be held in Room A of the lowa City Public Library. Your two-page proposals will also be } \\
\text { available for the public to take. Your teams will be held to the highest standards on these presentations so prepare } \\
\text { accordingly. } \\
\text { DUE: Reinvent the Toilet Challenge Team Presentation } \\
\text { DUE: Reinvent the Toilet Challenge Team Proposal } \\
\text { DUE: Individual 3D drawing of the solar powered well pump system using SketchUp. }\end{array}$ \\
\hline \multirow[t]{2}{*}{ Mar 20} & Week 9: Spring Break \\
\hline & World Water Day, Friday, March $22^{\text {nd }}$. Celebrate with your friends. \\
\hline \multirow[t]{2}{*}{ Mar 27} & Week 10: Workshop 1 \\
\hline & $\begin{array}{l}\text { Meet at the Hydraulics East Annex. Enter through the south door, nearest the UI Motor Pool parking lot. } \\
\text { Abney Level Surveying; Solar-powered Water Pumping; Chlorine Disinfection; Latrine Slab Construction; Brick Laying; Drinking } \\
\text { Water Tap Stand Construction }\end{array}$ \\
\hline \multirow[t]{2}{*}{ Apr 3} & Week 11: Workshop 2 \\
\hline & Meet at the Hydraulics East Annex. \\
\hline \multirow[t]{2}{*}{ Apr 10} & Week 12: Workshop 3 \\
\hline & Meet at the Hydraulics East Annex. \\
\hline \multirow[t]{2}{*}{ Apr 17} & Week 13: Workshop 4 \\
\hline & Meet at the Hydraulics East Annex. \\
\hline \multirow[t]{2}{*}{ Apr 24} & Week 14: Workshop 5 \\
\hline & Meet at the Hydraulics East Annex. \\
\hline \multirow[t]{2}{*}{ May 1} & Week 15: Workshop 6 \\
\hline & Meet at the Hydraulics East Annex. \\
\hline \multirow[t]{2}{*}{ May 8} & Week 16: Workshop Results Presentations \\
\hline & Meet at the Main Library classroom. \\
\hline $\begin{array}{l}\text { May } \\
13-17\end{array}$ & $\begin{array}{l}\text { Week 17: Finals Week } \\
\text { To Be Determined }\end{array}$ \\
\hline
\end{tabular}

